\title{
A PÓS-EFICÁCIA DAS OBRIGAÇÕES REVISITADA / THE POST-EFFECTIVENESS OF OBLIGATIONS REVISITED
}

\author{
Mauricio Mota $^{1}$
}

\begin{abstract}
RESUMO
Neste texto revisitado procuramos analisar a pós-eficácia das obrigações, ou seja, a subsistência de deveres pós-eficazes após o término do adimplemento do contrato, no interesse da correta consecução deste. Define-se aqui o âmbito e a natureza jurídica da póseficácia das obrigações, sua distinção em relação a outras situações jurídicas análogas e sua fundamentação dogmática. Por fim se conclui que o dever acessório de lealdade da póseficácia das obrigações configura uma situação de responsabilidade civil contratual, derivando diretamente dos princípios sociais do Código Civil: a boa-fé, o equilíbrio contratual e a função social dos contratos.
\end{abstract}

PalaVRas-CHAVE: Pós-eficácia das obrigações - Boa-fé objetiva - Deveres laterais de conduta - Responsabilidade civil contratual - Função social dos contratos.

\section{ABSTRACT}

This text revisited trying to analyze the post-effectiveness of obligations, in other words, the livelihood of post-effectives duties after the end of the completion of a the contract, in the interest of achieving of this contract. It is defined here the scope and legal nature of the posteffectiveness of obligations, their distinction in relationship to other legal situations of similar reasoning and its dogmatic. Finally we conclude that the duty of loyalty of posteffectiveness of obligations set a situation of contractual liability leading directly from the social principles of the Civil Code: a good-faith, the contractual equilibrium and the social function of the contract.

KEYWORDS: Post-effectiveness of obligations - Good faith - Secondary contract obligations - Contractual liability - Social function of the contract

SUMÁRIO: Introdução. 1. Os princípios sociais do Código Civil - 2. A obrigação no sentido moderno e o surgimento da noção de pós-eficácia das obrigações - 3. A noção de relações

\footnotetext{
${ }^{1}$ Doutor em Direito Civil pela UERJ. Professor da UERJ (graduação e pós-graduação).
} Procurador do Estado do Rio de Janeiro 
pós-contratuais - 4. Fundamentos da pós-eficácia das obrigações - 5. Distinção da póseficácia das obrigações das figuras jurídicas afins aproximadas - 6. A pós-eficácia das obrigações stricto sensu -7 . O regime jurídico da pós-eficácia das obrigações -8 .

Conclusão - 9. Referências.

Introdução

A pós-eficácia das obrigações é um dos temas intrincados do direito civil. Já no ano 2000 enfrentamos a matéria ${ }^{2}$, procurando naquela época balizar alguns contornos do instituto, como o âmbito e a natureza jurídica da pós-eficácia das obrigações, sua distinção em relação a outras situações jurídicas análogas, sua fundamentação dogmática e ressaltar, sobretudo, que, no Brasil, pioneiramente, em 1914, o Supremo Tribunal Federal já discutia a pós-eficácia da obrigação de cessão de clientela na compra e venda de estabelecimento comercial $^{3}$.

Com o advento do Código Civil de 2002 e a positivação dos princípios da boafé objetiva, do equilíbrio contratual e da função social dos contratos, é o momento de revisitar o tema, verificando sua transformação à luz dos novos paradigmas da eticidade, da operabilidade e da socialidade ${ }^{4}$ introduzidos pelo Código e, principalmente, tendo em vista o vasto labor doutrinário e jurisprudencial realizado no direito civil para adequá-lo aos princípios da solidariedade social e da dignidade da pessoa humana insculpidos na Constituição da República.

Buscou-se ao longo do texto construir um referencial teórico-dogmático da

\footnotetext{
${ }^{2}$ MOTA, Mauricio. A pós-eficácia das obrigações. In: TEPEDINO, Gustavo (org.). Problemas de direito civilconstitucional. Rio de Janeiro : Renovar, 2000, pp. 187-241.

${ }^{3}$ Ver em: BARBOSA, Rui. As cessões de clientela e a interdição de concorrência nas alienações de estabelecimentos comerciais e industriais. Obras Completas de Rui Barbosa. Vol. XL. Tomo I. Rio de Janeiro : Ministério da Educação e Saúde, 1948 e MENDONÇA, Joaquim Xavier Carvalho de. Apelação no 2183. Memorial da Apelante ao Supremo Tribunal Federal. Rio de Janeiro : Liga Marítima Brasileira, 1912. ${ }^{4}$ MARTINS-COSTA, Judith \& BRANCO, Gerson Luiz Carlos. Diretrizes teóricas do novo Código Civil brasileiro. São Paulo: Saraiva, 2002, p. 131.
}

Revista Quaestio luris, vol.04, n0.01. ISSN 1516-0351 p.351-423 352 
pós-eficácia das obrigações, acentuando o papel primordial desempenhado no ordenamento civil pelos novos princípios sociais dos contratos: a função social dos contratos, o princípio da boa-fé objetiva e o princípio do equilíbrio contratual. Esses princípios implicam na substancialização dos direitos e, assim, impõem uma nova consideração da eficácia das obrigações após a extinção do contrato.

A seguir se esboça a transformação da idéia de obrigação, com a compreensão de sua nova perspectiva totalizante, a existência de deveres laterais de conduta exigíveis além da obrigação principal e o surgimento da noção de violação positiva do contrato por descumprimento desses referidos deveres laterais. Afirma-se então a noção de pós-eficácia das obrigações, no âmbito da função integrativa da boa-fé objetiva, como um dever lateral de lealdade. Esse dever lateral de lealdade é esmiuçado em seus elementos primordiais e em seu desenvolvimento histórico.

Continuando, aborda-se a noção de relações pós-contratuais, estipulando a identificação do período pós-contratual, a partir de seu elemento chave: a extinção do contrato. Diferencia-se, nessa passagem, as situações exclusivas do período pós-contratual, mas que não configuram relações pós-contratuais.

O texto prossegue enfrentando a questão da correta fundamentação da póseficácia das obrigações, que deve ser buscada primordialmente nos já citados princípios da boa-fé objetiva, da função social dos contratos e do equilíbrio contratual.

Ponto importante que se ressalta, em continuidade, é o de que a pós-eficácia das obrigações insere-se no âmbito dos deveres acessórios de lealdade, de preservação do escopo da obrigação extinta, mas distingue-se totalmente de outras figuras jurídicas afins aproximadas como a pós-eficácia aparente, a pós-eficácia virtual e a eficácia continuada.

No cerne do trabalho define-se que a pós-eficácia das obrigações constitui um dever acessório de conduta, no sentido de que a boa-fé exige, segundo as circunstâncias, que os contratantes, depois do término da relação contratual, omitam toda conduta mediante a qual a outra parte se veria despojada ou essencialmente reduzidas as vantagens oferecidas pelo contrato. Esses deveres acessórios se consubstanciam primordialmente em deveres de reserva quanto ao contrato concluído, dever de segredo dos fatos conhecidos em função da 
participação na relação contratual e deveres de garantia da fruição pela contraparte do resultado do contrato concluído.

Em seguida enfrenta-se o tema mais tormentoso da matéria, o regime jurídico da pós-eficácia das obrigações, com um amplo panorama das posições doutrinárias sobre a controvérsia, se os deveres laterais de conduta posteriores à extinção das obrigações nucleares do contrato teriam natureza contratual ou extra-contratual. Nessa oportunidade são trazidas as contribuições do direito alemão, português, francês e argentino e se fixa a compreensão da matéria à luz do nosso ordenamento jurídico, consoante a eticidade definida pelo Código Civil.

Intenta-se aqui demonstrar que em nossa sociedade hipercomplexa cabe ao direito civil atuar como um mecanismo em que os atores sociais reduzem a complexidade interna do seu sistema de interação. Isto ocorre pela adoção de expectativas específicas sobre o comportamento futuro dos outros contratantes, pela seleção de possibilidades, podendo basear-se em processos históricos, em características compartilhadas ou em mecanismos institucionais. Assim, impõe-se a consideração do regime contratual desses deveres póseficazes, como demonstraremos.

Em suma, procura-se aqui gizar um retrato, o mais completo possível, do estado da arte da compreensão da pós-eficácia das obrigações, de modo a possibilitar a construção de um arcabouço teórico para a solução de problemas e controvérsias contratuais.

\section{Os princípios sociais do Código Civil}

A questão da modificação da natureza das obrigações em nosso direito, de modo que hoje já seja possível se conceber obrigações que possam subsistir após a extinção do contrato, importa no exame, no Código Civil brasileiro, no que concerne aos princípios contratuais, da positivação dos novos princípios sociais. Esses princípios são a função social dos contratos, o princípio da boa-fé objetiva e o princípio do equilíbrio contratual.

a) A função social dos contratos

Revista Quaestio luris, vol.04, no01. ISSN 1516-0351 p.351-423 354 
A função social dos contratos está prevista nos artigos 421 e 2035, parágrafo único, do Código Civil brasileiro.

O conceito de função social no direito em sua acepção contemporânea é bem ressaltado por Louis Josserand que enfatiza a natureza relacional e a imbricação dos direitos:

\begin{abstract}
toda prerrogativa, todo poder jurídico, são sociais em sua origem, na sua essência e até na missão que estão destinados a cumprir; como poderia ser de outra forma, já que o direito objetivo, tomado no seu conjunto, a 'juridicidade', não é outra coisa senão a regra social obrigatória? A parte não poderia ser de natureza diferente do todo ${ }^{5}$.
\end{abstract}

Assim, com a funcionalização dos direitos supera-se a idéia tradicional de que a esfera dos particulares é regulada pela noção de autonomia da vontade expressa no contrato $^{6}$. A concepção de vínculo contratual deixa de lastrear-se na idéia de valor da vontade, como elemento principal, como fonte única, para o nascimento de direitos e obrigações oriundos da relação jurídica contratual ${ }^{6}$. Isso significa dizer que o contrato, qualquer contrato, tem importância para toda a sociedade e seus fins próprios devem ser assegurados. O interesse geral, o bem comum, constitui limite à realização dos interesses individuais, subjetivos, do credor. Quem se arroga a condição de credor tem necessariamente um qualquer interesse em que o devedor realize a prestação, mas, evidentemente, o direito não poderá tutelar interesses que porventura sejam fúteis, ou por outra forma estranhos ao bem comum. Para além dos interesses do credor, e transcendendo mesmo os interesses conjuntos do credor e do devedor, estão os valores maiores da sociedade, que não podem ser $\operatorname{afetados}^{8}$.

Não há que se falar, contudo, em supressão da liberdade contratual que continua a ser um dos pilares da teoria contratual. Ocorre sim, uma funcionalização desta liberdade, diante da totalidade dos interesses sociais. A mudança de paradigma acontece

\footnotetext{
${ }^{5}$ JOSSERAND, Louis. De l'esprit des droits et de leur relativité - Théorie dite de l'Abus des droits. Paris : Dalloz, 1927, p. 292. 6

Para uma profunda análise acerca do conceito de autonomia da vontade, ver, por todos, GOUNOT, Emmanuel. Le principe de l'autonomie de la volonté en droit privé : contribution à l'étude critique de l'individualisme juridique. Paris : Arthur Rousseau, 1912.

${ }^{6}$ SAVIGNY, Friedrich Karl Von. Sistema del derecho romano actual. Tomo II. Madri : F. Góngora Editores, 1879, p. 354. 8

NORONHA, Fernando. Direito das obrigações: fundamentos do direito das obrigações. v. 1. São Paulo : Saraiva, 2003, p. 27.
} 


\section{Quaestio Iuris}

quando se percebe que a vontade individual não é suficiente para fundamentar a força obrigacional do contrato. A órbita de eficácia do negócio jurídico transcende - e muito - a esfera de interesses de cada parte. Há, então, uma mudança no perfil do contrato, com vistas a adaptá-lo à nova realidade social.

A função social dos contratos influi, sobretudo, na modificação de dois aspectos do vínculo contratual: a relatividade e a oponibilidade dos efeitos dos contratos.

O princípio da relatividade dos efeitos dos contratos significava tradicionalmente que os efeitos do vínculo contratual, vale dizer, a criação, extinção ou modificação de situações jurídicas subjetivas, situam-se no plano interno dos contratantes, atingindo apenas as partes que consentiram na formação do contrato. Em outras palavras, os direitos e deveres decorrentes do contrato vinculavam apenas as partes, não obrigando, tampouco beneficiando terceiros (res inter alios acta tertio neque nocet neque prodest) ${ }^{7}$.

Com a especificação no Código dos princípios da função social dos contratos e da solidariedade social, estes, ao incidirem diretamente nas situações jurídicas subjetivas, remodelam o princípio da relatividade, permitindo, em alguns casos, a extensão de direitos e a imposição de deveres contratuais a terceiros estranhos à formação do vínculo obrigacional. Assim, o reconhecimento do direito da vítima de acidente de trânsito de acionar diretamente a seguradora do ofensor e pleitear, em face dela, reparação pelos danos sofridos ${ }^{8}$. Para além

\footnotetext{
${ }^{7}$ Para uma análise completa acerca do princípio da relatividade dos efeitos dos contratos, ver, por todos: BACACHE-GIBEILI, Mireille. La relativité des conventions et les groups de contrats. Paris : LGDJ, 1996. Em uma abordagem mais tradicional: CALASTRENG, Simone. La relativité des conventions : étude de l'article 1165 du Code civil. Paris : Recueil Sirey, 1939.

${ }^{8}$ Essa é a jurisprudência do Superior Tribunal de Justiça - STJ em diversos precedentes, como se vê de trecho do voto da Ministra Nancy Andrighi: "De fato, a interpretação do contrato de seguro dentro desta perspectiva social autoriza e recomenda que a indenização prevista para reparar os danos causados pelo segurado ao terceiro seja por este diretamente reclamada da seguradora. Assim, sem se afrontar a liberdade contratual das partes - as quais quiseram estipular uma cobertura para a hipótese de danos de terceiros - maximiza-se a eficácia social do contrato com a simplificação dos meios jurídicos pelos quais o prejudicado pode haver a reparação que lhe é devida. Cumpre-se o princípio constitucional da solidariedade e garantese a função social do contrato" (STJ, REsp 444.716-BA, $3^{\mathrm{a}}$ T., Rel. Min. Nancy Andrighi, v.u., julg.11.5.2004). Confira-se ainda: STJ, REsp. 228840, $3^{\mathrm{a}}$ T., Rel. Min. Ari Pargendler, Rel. p/ acórdão Min. Carlos Alberto Menezes Direito, julg. 26.6.2000, publ. DJ 4.9.2000. V. também STJ, REsp. 401718, $4^{\text {a }}$ T., Rel. Min. Sálvio de Figueiredo Teixeira, julg. 3.9.2002, publ. DJ 24.3.2003; STJ, REsp. 294057, 4 T., Rel. Min. Ruy Rosado de Aguiar, julg. 28.6.2001, publ. DJ 12.11.2001; e STJ, REsp. 97590, $4^{\mathrm{a}}$ T., Rel. Min. Ruy Rosado de Aguiar,
} 
das exceções tradicionalmente admitidas ao princípio da relatividade, reconhece-se sua mitigação em determinadas hipóteses nas quais isso se afigure indispensável à proteção de interesses, no caso concreto, merecedores de tutela, os quais em ponderação com a liberdade de contratar, sejam preponderantes ${ }^{11}$.

Outro exemplo da flexibilização do princípio em tela se consubstancia nos chamados contratos coletivos de trabalho, cujos efeitos são aplicáveis a todos os membros de uma determinada categoria, incluindo-se aqueles que não participaram da negociação, visto que suas cláusulas têm conteúdo normativo ${ }^{12}$.

Também importantes conseqüências da função social dos contratos podem ser vislumbradas no princípio da oponibilidade dos efeitos dos contratos.

A oponibilidade opera no plano da existência do contrato, terreno em que o princípio da relatividade não se aplica, uma vez que dizer que os efeitos não atingem terceiros não significa que o contrato não exista em face de terceiros. A oponibilidade decorre do reconhecimento de que o contrato é um fato social, o qual reflete uma realidade exterior a si próprio, uma gama variada de interesses, relações, situações econômicosociais, não se limitando a um mero conceito jurídico. Deste modo, impõe-se a todos - partes e terceiros - a necessidade de reconhecerem a existência do contrato e, conseqüentemente, de o respeitarem.

Com relação a esses efeitos externos, a função social dos contratos impõe que se passe a vislumbrar a relação contratual de maneira mais ampla. Celebrado o contrato, o acordo de vontades entre duas ou mais partes, toda a coletividade passa a ter o dever de

julg. 15.10.1996, publ. DJ 18.11.1996. Invoque-se, ainda, a hipótese em que o STJ impediu a penhora de imóvel hipotecado à instituição de crédito imobiliária em garantia de dívida da construtora decorrente do financiamento da construção do edifício, tendo em vista o contrato de promessa de compra e venda celebrado entre o terceiro promitente-comprador e a construtora, mediante o qual o promitente-comprador já teria adimplido integral ou parcialmente suas prestações. Neste caso, nitidamente, a financeira, terceiro em relação ao contrato de promessa de compra e venda, foi impedida de exercer o seu direito de seqüela inerente à garantia real hipotecária por força deste contrato. Confira-se: STJ, REsp. 187940, 4ª T., Rel. Min. Ruy Rosado de Aguiar Júnior, julg. 18.2.1999, publ. DJ 21.6.1999.

11 Para uma análise completa acerca da ação direta, ver, por todos: JAMIN, Christophe. La notion d'action directe. Paris : LGDJ, 1991. 12 Trata-se aqui de "ato-regra" ou comando abstrato. São, pois, deste ponto de vista substantivo (de seu conteúdo),diplomas desveladores de inquestionáveis regras jurídicas embora existam, também no seu interior, cláusulas contratuais. Na verdade, os convênios coletivos de trabalho, embora de origem privada, criam regras jurídicas (normas autônomas), ou seja, preceitos gerais, abstratos e impessoais, destinados a normatizar situações ad futurum, correspondendo, assim, à noção de lei em sentido material. Todavia, sob o aspecto formal, despontam como verdadeiros acordos de vontade entre sujeitos coletivos, inscrevendo-se, por conseqüência, na mesma categoria dos negócios jurídicos privados bilaterais ou plurilaterais. 
respeitar e zelar pelo fim preconizado por aqueles particulares. Na medida em que o contrato é um fato social, ele ingressa em determinado meio, gerando aos demais - meros

espectadores, até então - o dever geral de abstenção. Sob esse ponto de vista, mesmo que não sejam partes do contrato, terceiros têm o dever de respeitar os seus efeitos no meio social, porque o negócio jurídico tem relevante papel na ordem econômica e no aprimoramento da sociedade. Têm também, os terceiros, direito de evitar conseqüências danosas e injustas em suas esferas particulares, que o contrato, desviado de sua função social, eventualmente produza ou ameace produzir?.

O desenvolvimento econômico deve ocorrer simultaneamente ao social. Ambos representam os pilares de uma sociedade justa e igual, não se desligando, por óbvio, do princípio maior que é o da dignidade da pessoa humana, que não pode ser ferido em nome de valores econômicos ou mesmo sociais.

b) O princípio da boa-fé objetiva

\section{O princípio da boa-fé objetiva está consagrado no art. 422 do Código Civil}

brasileiro e corresponde à cláusula geral de boa-fé, própria dos ordenamentos europeus continentais.

Esse princípio da boa-fé se expressa e vincula o ordenamento através da noção de cláusula geral. Essa constitui numa técnica legislativa, uma disposição normativa que utiliza, no seu enunciado, uma linguagem de tessitura intencionalmente "aberta", "fluida" ou "vaga", caracterizando-se pela ampla extensão do seu campo semântico, a qual é dirigida ao juiz de modo a conferir ele um mandato (ou competência) para que, à vista dos casos concretos, crie, complemente ou desenvolva normas jurídicas, mediante o reenvio para elementos cuja concretização pode estar fora do sistema; estes elementos, contudo,

\footnotetext{
${ }^{9}$ Sobre a matéria ver: CARDOSO, Patrícia. Oponibilidade dos efeitos dos contratos: determinante da responsabilidade civil do terceiro que coopera com o devedor na violação do pacto contratual. Revista Trimestral de Direito Civil, v. 20, out./dez. 2004.
}

Revista Quaestio luris, vol.04, no01. ISSN 1516-0351 p.351-423 358 
fundamentarão a decisão, motivo pelo qual, reiterados no tempo os fundamentos da decisão, será viabilizada a ressistematização desses elementos originariamente extrasistemáticos no interior do ordenamento jurídico ${ }^{10}$.

A boa-fé objetiva, que os alemães definem por Treu und Glauben (lealdade e crença), é assim um dever global - dever de agir de acordo com determinados padrões, socialmente recomendados, de correção, lisura e honestidade para não frustrar a confiança da outra parte.

Três são as notas características da boa-fé objetiva. A primeira pressupõe a existência de duas pessoas ligadas por uma determinada relação jurídica, que lhes imponha especiais deveres de conduta, de cada uma delas em relação à outra, ou, pelo menos de uma delas em relação à outra.

Esses deveres, a segunda nota característica, são aqueles referentes ao comportamento exigível do bom cidadão, do profissional competente, enfim, de uma pessoa diligente, comportamento este expresso na noção de bonus pater familias.

Deve-se observar também se a situação criada produziu na contraparte um estado de confiança no negócio celebrado, quando então deverá se tutelar essa expectativa. Desde que a contraparte tenha legitimamente confiado na estabilidade e segurança do negócio jurídico que celebrava impõe-se a tutela dessa confiança pelo princípio da boa-fé objetiva ${ }^{11}$.

Na concepção objetiva, a boa-fé contrapõe-se à ausência de boa-fé e não à má fé. Assim, em princípio, a atuação em desconformidade com os padrões de conduta exigíveis caracteriza violação do dever de agir de boa-fé (objetiva), mesmo sem má fé (ou dolo) e sem culpa. Portanto, nem sempre a atuação não conforme a boa-fé (objetiva) será ilícita, mas, mesmo quando não ilícita, em princípio, continuará sendo geradora de responsabilidade ${ }^{16}$.

A obrigação contratual no sentido moderno pode ser entendida portanto como um dever global de agir objetivamente de boa-fé. Essa boa-fé objetiva constitui no campo contratual um processo que deve ser seguido nas várias fases das relações entre as partes.

\footnotetext{
${ }^{10}$ MARTINS-COSTA, Judith. A boa-fé no direito privado: sistema e tópica no processo obrigacional. São Paulo : Revista dos Tribunais, 1999, p. 303.

${ }^{11}$ NORONHA, Fernando. O direito dos contratos e seus princípios fundamentais: autonomia privada, boa-fé e justiça contratual. São Paulo : Saraiva, 1994, p. 137/138. ${ }^{16}$ Ibidem. p. 140.
}

Revista Quaestio luris, vol.04, no01. ISSN 1516-0351 p.351-423 359 
Assim, na fase pré-contratual, das negociações preliminares à declaração de oferta, os contraentes devem agir com lealdade recíproca, dando as informações necessárias, evitando criar expectativas que sabem destinadas ao fracasso, impedindo a revelação de dados obtidos em confiança, não realizando rupturas abruptas e inesperadas das conversações etc.

Na fase contratual, a conduta leal implica em vários deveres acessórios à obrigação principal, e, na fase pós-contratual, implica em deveres posteriores ao término do contrato - deveres post pactum finitum - como o de guarda de documentos, fornecimento de material de reposição ou informações a terceiros sobre os negócios realizados ${ }^{12}$.

A boa-fé contratual definida assim como um processo desdobra-se em diferentes funções: a função interpretativa da boa-fé, a função integrativa da boa-fé e a função de controle da boa-fé.

A idéia de que os negócios jurídicos devem ser interpretados de acordo com a boa-fé objetiva significa que os contratos e os negócios jurídicos unilaterais devem ser interpretados de acordo com o seu sentido objetivo, aparente, salvo quando o destinatário conheça a vontade real do declarante, ou quando devesse conhecê-la, se agisse com razoável diligência; quando o sentido objetivo suscite dúvidas, dever-se-á preferir o significado que a boa-fé aponte como o mais razoável ${ }^{13}$.

Visa tal idéia de interpretação amparar a tutela da confiança do destinatário da declaração, bem como a assegurar o valor real da aparência, sendo tais elementos essenciais ao intercâmbio de bens e serviços e à segurança das transações.

A segunda acepção da função interpretativa da boa-fé é a que diz respeito à significação a atribuir ao contrato, quando contenha cláusulas ambíguas, isto é, cláusulas cujo próprio sentido objetivo seja duvidoso.

Quando em presença de cláusulas ambíguas deve-se preferir o significado que

\footnotetext{
${ }^{12}$ AZEVEDO, Antonio Junqueira de. Responsabilidade pré-contratual no Código de defesa do consumidor: estudo comparado com a responsabilidade pré-contratual no direito comum. Revista de Direito do Consumidor $\mathrm{n}^{\circ}$ 18, p. 23-31, abr./jun., 1996.

${ }^{13}$ Idéia que já pode ser encontrada em germe na terceira regra de interpretação dos contratos de Pothier: quando em um contrato os termos são suscetíveis de dois sentidos, devem-se entender no sentido que mais convém à natureza do contrato. POTHIER, R-J. Tratado das obrigações pessoaes e recíprocas. Tomo I. Rio de Janeiro : H. Garnier Editor, 1906, p. 62.
} 
a boa-fé aponte como o mais razoável. São principalmente estes os os meios pelos quais a jurisprudência vem procurando dar conta de tais hipóteses:

a) pela aplicação do princípio da conservação do contrato, pelo qual deve-se escolher sempre, entre os diversos sentidos possíveis, o que assegure a preservação do contrato;

b) pela aplicação do princípio do menor sacrifício, ou seja, pela idéia de que o contrato deve ser interpretado no sentido mais favorável à parte que assume obrigações;

c) pela aplicação do princípio da interpretação contra o predisponente, pelo qual se deve interpretar o contrato sempre no sentido menos favorável a quem o redigiu, disposição esta particularmente relevante no que se refere aos contratos padronizados e de $\operatorname{adesão~}^{14}$.

A função integrativa da boa-fé compreende a idéia de que os deveres das partes não são, para cada uma, apenas o de realizar a prestação estipulada no contrato ou no negócio jurídico unilateral, eventualmente acrescido de outros deveres previstos pelas partes e ainda dos estabelecidos nas leis, mas que se impõe também a observância de muitos outros deveres de conduta, a partir da análise da obrigação de uma perspectiva sistêmica ou totalizante vocacionada para o adimplemento ${ }^{15}$.

O princípio da boa-fé regula não apenas a interpretação das cláusulas do contrato referida anteriormente, mas ainda o reconhecimento desses deveres secundários (não diretamente pactuados) derivados diretamente do princípio, independentemente da vontade manifestada pelas partes, a serem observados durante a fase de formação e de cumprimento da obrigação e mesmo, em alguns casos, após o adimplemento desta. São deveres que excedem o dever de prestação. Assim são os laterais de esclarecimento (informações sobre o uso do bem alienado, capacitações e limites), de proteção (evitar situações de perigo), de conservação (coisa recebida para experiência), de lealdade (não exigir o cumprimento de

\footnotetext{
${ }^{14}$ Idéia que também já pode ser encontrada em germe na sétima regra de interpretação dos contratos de Pothier: na dúvida, uma cláusula deve interpretar-se contra aquele que tem estipulado uma coisa, em descargo daquele que tem contraído a obrigação. POTHIER, R-J. Tratado das obrigações pessoaes e recíprocas. Tomo I. Rio de Janeiro : H. Garnier Editor, 1906, p. 64.

${ }^{15}$ NORONHA, Fernando. O direito dos contratos e seus princípios fundamentais: autonomia privada, boa-fé e justiça contratual. op. cit., p. 157.
}

Revista Quaestio luris, vol.04, no01. ISSN 1516-0351 p.351-423 361 
contrato com insuportável perda de equivalência entre as prestações), de cooperação (prática dos atos necessários à realização dos fins plenos visados pela outra parte) etc.

Esses deveres laterais de conduta, como acima considerados, podem ser definidos como deveres que, não interessando à obrigação principal, são todavia essenciais ao correto processamento da relação obrigacional em que a prestação se integra. São usualmente divididos em deveres de proteção, de esclarecimento e de lealdade. Os primeiros dizem respeito à obrigação das partes de evitar, no curso do fenômeno contratual, que sejam infligidos danos mútuos, nas suas pessoas ou nos seus patrimônios.

Os segundos obrigam as partes a, na vigência do contrato, informarem-se mutuamente de todos os aspectos atinentes ao vínculo, de ocorrências que com ele tenham relação e, ainda, de todos os efeitos que, da execução contratual, possam advir. Os deveres de lealdade obrigam as partes a absterem-se de comportamentos que possam falsear o objetivo do negócio ou desequilibrar o jogo das prestações por elas consignado ${ }^{16}$.

Tal criação de deveres jurídicos não expressamente estipulados pelas partes é possível se entendemos o sistema jurídico como uma totalidade sistêmica, disposta num processo, vocacionada para o adimplemento. Os deveres secundários comportam tratamento que abrange toda a relação jurídica. Assim, podem ser examinados durante o curso com o desenvolvimento da relação jurídica, e, em certos casos, posteriormente ao implemento da obrigação principal.

Essa autonomia e mesmo pós-eficácia dos deveres anexos explica-se pelo sentido teleológico da obrigação, que comanda toda a relação jurídica e conforma os deveres e direitos que a relação jurídica produz em contato com a realidade social no curso do seu desenvolvimento, levando esses deveres, para correto cumprimento da obrigação, a ter fim próprio, diverso da obrigação principal ${ }^{17}$.

A função de controle da boa-fé objetiva é limitativa: ela estabelece que o credor, no exercício do seu direito, não pode exceder os limites impostos pela boa-fé, sob pena de proceder antijuridicamente.

\footnotetext{
${ }^{16}$ CORDEIRO, Antonio Manuel da Rocha e Menezes. Da boa-fé no direito civil. v. I. Coimbra : Almedina, 1984, p. 604 e ss.

${ }^{17}$ SILVA, Clóvis Veríssimo do Couto e. Obrigação como processo. Rio de Janeiro : FGV, 2006, p. 97.
}

Revista Quaestio luris, vol.04, no01. ISSN 1516-0351 p.351-423 362 
O exemplo mais significativo é o da proibição do exercício de resolver o contrato por inadimplemento, ou de suscitar a exceção do contrato não cumprido, quando o não cumprimento é insignificante em relação ao contrato total ${ }^{23}$.

c) O princípio do equilíbrio contratual

O princípio do equilíbrio contratual pode ser inferido dos artigos 478 a 480 do Código Civil e também de outras regras do mesmo Código (arts. 157, 317, 616, 620, 770 parte final, 924 , etc.. $)^{24}$.

A idéia de equilíbrio na relação entre particulares encontra sua primeira formulação completa e acabada no direito romano.

No direito romano não existia uma noção abstrata de contractus, ao qual o ordenamento jurídico vinculava o efeito de produzir obligationes. Não se reconhecia autonomia à vontade dos sujeitos, no sentido de que não podiam estabelecer a seu gosto o conteúdo de seus acordos. Se estes estavam dirigidos a constituir relações patrimoniais que não correspondiam aos tipos particulares fixados pelo ius civile, o ordenamento jurídico não reconhecia sua capacidade de constituir vínculos obrigatórios. Na asserção de Eduardo Volterra, esta antítese entre o direito romano e o moderno pode ser expressa, de forma sintética, dizendo-se que enquanto o direito positivo atual conhece o contrato em geral, o direito romano só conhece contratos particulares ${ }^{25}$.

Isso se explica porque os romanos elaboram sua ciência do direito partindo não de construções geométricas (axiomas como a liberdade primitiva do indivíduo ou a soberania da lei), mas sim observando o dado social natural, interrogando a natureza, tentando reencontrar a ordem que ela acolhe; ordem de caráter objetivo, e portanto jurídico. Sua jurisprudência é voltada para o conhecimento das coisas (D. 1, 1, 10, 2), é uma descrição das coisas e da natureza das coisas ${ }^{18}$.

\footnotetext{
${ }^{18}$ VILLEY, Michel. Seize essais de philosophie du droit dont un sur la crise universitaire. Paris : Dalloz, 1969, p.
} 243. 
Para os romanos o direito é um objeto exterior ao homem, uma coisa, a mesma coisa justa (ipsa iusta res) que constitui o término do atuar justo de uma pessoa, a finalidade da virtude da justiça. A conduta justa do homem justo (dikaios) é a justiça em mim, subjetiva, o direito (dikaion) é a justiça fora de mim, no real, a mesma coisa justa, objetiva. O direito está assim fora do homem, in re, nas coisas justas, de acordo com uma determinada proporção, o justo meio objetivo.

O direito é, deste modo, uma relação entre substâncias, por exemplo, entre casas e somas em dinheiro que, numa cidade, se repartem entre seus proprietários. O direito é, com efeito, uma coisa exterior que se extrai de uma natureza relacional entre duas ou mais pessoas que disputam bens, encargos e honras.

Assim, em um litígio, o direito será a justa parte que corresponde a cada uma das pessoas envolvidas nele, o que significa reconhecer que não somente resulta impossível concebê-lo à margem das relações interpessoais (por exemplo, na solidão de Robinson Crusoé em sua ilha) senão que, também, este direito é necessariamente finito, limitado (é a parte justa de uma relação concreta ${ }^{19}$.

Ao direito antigo, então, é estranha a nossa noção de direito subjetivo e toda temática de direitos individuais como absolutos e exclusivos de cada pessoa, sem conexão e, portanto, sem limitação inicial alguma com os demais.

O direito antigo, assim pensado, não é rigorosamente individual. Não supõe para o indivíduo somente um ativo, só vantagens; meu direito, isso que me deve ser dado, isso que eu mereço, não é "subjetivo", não se refere somente a um indivíduo, implica necessariamente em uma relação entre indivíduos. É o resultado de uma repartição. Na dicção de Aristóteles o direito apenas é um atributo da minha pessoa, não é exclusivamente meu na medida em que é primordialmente o bem de outrem:

Considera-se que a justiça, e somente ela entre todas as formas de excelência moral, é o 'bem dos outros'; de fato, ela se relaciona com o próximo, pois faz o que é vantajoso para os outros, quer se trate de um governante, quer se trate de um companheiro da comunidade" 20 .

\footnotetext{
${ }^{19}$ CABANILLAS, Renato Rabbi-Baldi. La filosofía jurídica de Michel Villey. Pamplona : Universidad de Navarra, 1990, p. 158-160.

${ }^{20}$ ARISTÓTELES. Ética a Nicômacos. 4. ed. Brasília : UNB, 2001, p. 93.
}

Revista Quaestio luris, vol.04, no01. ISSN 1516-0351 p.351-423 364 
O direito - o justo de cada um - emerge de uma repartição concreta, é uma proporção (justa, um igual [ison] ou analagon, termo gramaticalmente neutro). Essa igualdade expressa, consoante a matemática grega, uma cosmovisão integrada da totalidade, não a constatação de uma simples equivalência de fato entre quantidades, mas revela a harmonia, o valor do justo, uma certa ordem que se discerne no caso mesmo e que se acha em conexão, em última instância, com a ordem geral do mundo que é a matéria da justiça geral. O direito nesse contexto não é, senão, uma coisa exterior ao sujeito, uma certa igualdade que reside nas coisas, na realidade, in re, e que se extrai da observação da natureza:

É uma outra passagem da Ética, que trata do conhecimento do conteúdo da justiça. Sabese a primeira resposta de Aristóteles : nós extraímos de resto o justo da observação da natureza; ele é as leis constituídas segundo a natureza. Há um justo, há um direito natural. Ao método subjetivo, que pretende deduzir a justiça dos princípios da razão externa, vem se opor um outro método, que a procura fora de nós mesmos, no mundo exterior. Nós estamos aqui no coração da doutrina do direito natural (tradução livre) $)^{21}$.

É a concepção do direito romano que Paulo define no livro XIV ad Sabinum (D.1, 1, 11):

D. $1,1,11$

PAULUS libro XIV ad Sabinum

O direito pode ser dito de muitos modos: de um modo, como se chama direito aquilo que é sempre justo e bom, como é o direito natural. ${ }^{30}$.

O direito não pode ser estimado senão do processo de interrogação da natureza, de tentar reencontrar a ordem que ela acolhe; ordem de cunho objetivo, e, portanto, jurídico. Para o direito antigo só a natureza é suscetível de dar às questões dos juristas respostas substanciais.

No que concerne às relações societais, o direito romano encontra na cena jurídica as trocas ou, mais genericamente as relações de negócio, negotia (D. 50, 16, 19):

\footnotetext{
"Ulpiano; Comentarios al Edicto, libro XI

Labeon define en el libro primero del Pretor urbano, que unas cosas se hacen, otras se gestionan, y otras se contratan. Y ciertamiente que la palabra 'acto' es general, ya sea alguna cosa se haga de palabra, ya sea que realmente, con en él estipulación, o en la entrega de cantidad; pero 'contrato' significa obligación de una y de otra parte, lo que los
}

\footnotetext{
${ }^{21}$ VILLEY, Michel. Abrégé du droit naturel classique. Archives de Philosophie du Droit. Paris, n. 06, p. 2572, 1961, p. 45. 30

JUSTINIANO. Digesto de Justiniano. Livro I. Tradução de Hélcio Maciel França Madeira. São Paulo : Revista dos Tribunais/UNIFIEO, 2000, p. 20.
}

Revista Quaestio luris, vol.04, no01. ISSN 1516-0351 p.351-423 365 
griegos llaman $\sigma \vee \gamma \alpha \lambda \lambda \xi \mu \alpha \mathrm{\alpha}$, como la compra, venta, locación, conducción y sociedad; 'gestionado's significa cosa hecha con palabras ${ }^{22}$.

É na descrição desta coisa, o negotium contractum e na "natureza" de cada negotium que o direito romano se aplica. A ciência jurídica romana se esforça por determinar em que consiste e, de resto, como têm nascimento essas relações de negócio, incluindo a existência de obrigações, suas causas de geração.

Como bem descreve Gaius (III, 89 e ss.), a obrigação contratual é produto primeiramente re (quer dizer, a entrega de uma coisa, a passagem de um valor de um patrimônio para o outro, como no mutuum ou no depósito). O vínculo obrigatório surge do fato de entregar uma coisa a outro sujeito para que a use numa determinada direção e a restitua, ou bem, se trata-se de uma coisa fungível, a consuma e transfira a quem lhe houver dado, depois de um certo tempo, outra coisa idêntica ${ }^{23}$.

No contrato há uma certa ação voluntária do sujeito que contratou (contrahit) que o fez de plena vontade - mas não necessariamente uma "convenção" de duas partes.

A causa geradora aparece situada na res e não no consentimento (D. 2,14,7,2):

"§ 2. - Pero si la cosa no pasare à otro contrato, y subsistiere, sin embargo, la causa, respondió acertadamente Ariston a Celso, que había obligación; por ejemplo, te di una cosa, para que me dieras otra; di para que hagas algo, esto es contrato, y de aquí nace una obligación civil" ${ }^{24}$.

A "causa" da obrigação, a razão de sua existência, é o fato de que o sujeito deu: dedi (te di). Este fato dá lugar à obrigação, ao menos incerta, para o outro de reembolsar o sujeito ou pagar o equivalente da contraprestação atendida ${ }^{25}$. A obrigação, baseada em uma causa determinada no ius civile, se aperfeiçoa, com o surgimento do vínculo obrigatório, se for acompanhada ou seguida do ato material de entrega da coisa ${ }^{26}$.

Os juristas clássicos têm muito clara a idéia de que o simples acordo das partes, a conventio, não é suficiente para que surja o contrato e, por conseguinte, o vínculo obrigatório; junto com o acordo deve existir a causa, quer dizer, é preciso que a vontade

\footnotetext{
${ }^{22}$ JUSTINIANO. Cuerpo del derecho civil romano. Tomo III. Digesto. $6^{\mathrm{a}}$ y $7^{\mathrm{a}}$ partes. Tradução de Idelfonso García del Corral. Valladolid : Lexnova, 1988, p. 914.

${ }^{23}$ VILLEY, Michel. Seize essais de philosophie du droit dont un sur la crise universitaire. op. cit., p. 243.

${ }_{25}^{24}$ JUSTINIANO. Cuerpo del derecho civil romano. Tomo I. Instituta-Digesto. op. cit., p. 276.

${ }^{25}$ VILLEY, Michel. Seize essais de philosophie du droit dont un sur la crise universitaire. op. cit. p. 243.

${ }^{26}$ VOLTERRA, Eduardo. Instituciones de derecho privado romano. op. cit. p. 460.
} 
acordada das partes se ordene ao ato de troca, ao qual se vinculam determinados efeitos jurídicos e consequiências concretas ${ }^{27}$. O princípio é assim definido por Ulpiano em D. 2, $14,7,4:$

Pero cuando no subsiste ninguna causa, es sabido que entonces por la convención no puede constituirse obligación. Por consiguiente, el nudo pacta no produce obligación, pero produce excepción ${ }^{37}$.

Assim, a noção romana de contractus não guarda relação com a idéia moderna. Com o termo contractus os juristas clássicos designam não uma situação subjetiva plúrima fundada na vontade e na liberdade de estipulação mas sim uma realidade objetiva na qual as manifestações de vontade de dois ou mais sujeitos que tendem a um mesmo fim devem amoldar-se a um estalão fixado de forma taxativa pelo ius civile e encaminhado a constituir entre os manifestantes uma relação de obligatio.

Muito pelo contrário, concebendo a realidade do direito como estando in re, os romanos descrevem tal natureza, ou seja, o regime do negotium: este dependerá de cada tipo de negócio.

Como exemplifica Villey, no mutuum, empréstimo entre vizinhos ou amigos, deve-se restituir o mútuo excluindo o recebimento de qualquer interesse. A convenção não tem neste nenhum papel: não pode modificá-lo. É simplesmente a justiça objetiva, dita comutativa, que o estabelece assim em razão da natureza do contrato. Mesmo nos contratos "consensuais" o efeito do contrato é função da natureza de cada negócio: se o vendedor deve dar garantias contra os vícios da coisa vendida não é porque as partes assim o tenham previsto, nem porque assim convencionaram. É o justo equilíbrio nas prestações recíprocas que o impõe, aquilo que o jurista romano persegue ${ }^{28}$.

Na sociedade burguesa moderna, predomina a noção de liberdade contratual com rigidez equivalente a ato de fé. As pessoas seriam suficientemente esclarecidas e livres para velarem por seus próprios interesses e, qualquer norma que outorgasse ao juiz poder

\footnotetext{
${ }^{27}$ ibid., p. 463. 37 JUSTINIANO. Cuerpo del derecho civil romano. I Parte. Instituta-Digesto. op. cit., 1988, p. 276.

${ }^{28}$ VILLEY, Michel. Seize essais de philosophie du droit dont un sur la crise universitaire. op. cit., p. 244.
} 
suficiente para intervir nas relações contratuais claramente iníquas, seria paternalista e prejudicial à segurança jurídica.

Sob esse prisma, não demorou muito para se verificar a desigualdade intrínseca das relações jurídicas, especialmente, na esfera contratual, passando a ser exigida a interferência dirigista do Estado a fim de corrigir o desequilíbrio existente, ensejando uma progressiva intervenção do Estado nas relações contratuais. No Brasil isso ficou expresso na Constituição Federal de 1988 que estabeleceu a exigência de relações justas e solidárias (art. $\left.3^{\circ}, \mathrm{I}\right)$.

Assim, em nosso direito, tanto na Constituição como no Código Civil, aplicase o princípio do equilíbrio contratual que procura garantir às partes o exercício materialmente igualitário da liberdade de contratar, que se torne efetiva e não sirva, em verdade, a escravizar qualquer das partes a quem se deve garantir a prerrogativa de se desvincular do ajuste mediante seu cumprimento normal e o atendimento das razoáveis expectativas que levaram a contratar. O estabelecimento das convenções deve pautar-se de acordo com ideais de justiça e eqüidade a fim de que não se avilte, de outro lado, a dignidade da pessoa humana e nem o solidarismo que se impõe como novo padrão de conduta das partes ao transacionarem, e que determina e assegura o equilíbrio de suas prestações.

A comutatividade nos contratos constitui-se por isso em princípio essencial do direito, uma vez que exige a equivalência das prestações e o equilíbrio delas, no curso das contratações. Por ele, as partes devem saber, desde o início da relação negocial, quais serão seus ganhos e suas perdas, importando esse fato à aludida eqüipolência das mencionadas prestações.

Como bem aduz Karl Larenz, deve-se buscar a proporção entre prestação e contraprestação através de um valor que seja razoável e aproximado, além da manifestação do princípio do equilíbrio contratual de forma objetiva pela equivalência entre prestação e contraprestação, segundo o princípio da justa distribuição de cargas (ou ônus) e riscos dos $\operatorname{contratos}^{29}$. Nesta senda, deve-se presumir, preservada a justiça formal da contratação, através da manifestação livre e igualitária de consentimento, a justiça substancial da divisão que os

\footnotetext{
${ }^{29}$ LARENZ, Karl. Base del negocio jurídico y cumplimiento de los contratos. Madrid: Revista de Derecho Privado, 1956, p. 225. 40 Para uma análise completa da lesão nos contratos no direito brasileiro, ver, por todos: BECKER, Anelise. Teoria geral da lesão nos contratos. São Paulo : Saraiva, 2000.
} 
próprios contratantes fizeram de suas vantagens e desvantagens decorrentes da harmonia irradiada dos princípios da autonomia da vontade e da justiça contratual substancial, de modo que as prestações e contraprestações sejam balanceadas no ajuste.

Portanto, verifica-se que o princípio do equilíbrio contratual está atrelado e relacionado a um ajuste que seja bilateral, sinalagmático e comutativo, e que se exija a necessária eqüidade entre prestações correspectivas, entre as vantagens e desvantagens do ajuste.

O princípio do equilíbrio econômico do contrato leva a ordem jurídica a proteger o contratante contra a lesão ${ }^{40}$ (art. 157, CC) e a onerosidade excessiva ${ }^{30}($ art. 478, $\mathrm{CC})$.

No primeiro caso torna-se anulável o contrato ajustado por quem age, sob premente necessidade ou por inexperiência, obrigando-se a prestação manifestamente desproporcional ao valor da prestação oposta (art.157, CC).

A lesão prevista no art. 157 compõe-se de elementos objetivos e subjetivos. O elemento objetivo diz respeito à equivalência das prestações. Pode esta ser determinada a partir de uma tarifa previamente estabelecida na lei, como um parâmetro quantitativo para a caracterização da lesão (metade do valor, sete doze avos, etc.), ou ser um conceito aberto, exigindo-se tão somente que as prestações sejam desproporcionais, segundo juízo emitido pelo julgador, no caso concreto. $\mathrm{O}$ art. 157 opta pelo conceito aberto sob a rubrica de manifesta desproporção. Sendo um negócio de boa-fé, a verificação do desequilíbrio deve levar em conta a totalidade do contrato e não apenas a desproporção entre prestação e contraprestação. Assim, também devem ser considerados, para a quantificação da desproporção, as vantagens excessivas concernentes aos deveres laterais de conduta e às circunstâncias de tempo, lugar ou modo do contrato.

São elementos subjetivos da lesão a premente necessidade ou a inexperiência do lesado. Não há necessidade de que a parte contrária, que seria beneficiada com a lesão, saiba que a manifestação de vontade foi emitida por necessidade ou inexperiência. $\mathrm{O}$ dispositivo é objetivo e ocorre independentemente de dolo ou culpa do beneficiado. Difere a

\footnotetext{
${ }^{30}$ Para uma análise aprofundada da onerosidade excessiva, ver, por todos: PÉROT-MOREL, Marie-Angèle. De l'equilibre dês prestations dans la conclusion du contrat. Paris : Dalloz, 1961; MARTORELL, Juan Terraza. Modificación y resolución de los contratos por excesiva onerosidad en su ejecución. Barcelona : Bosch, 1951.
} 
lesão qualificada aqui exposta da lesão usurária, pela irrelevância do dolo de aproveitamento para a qualificação do referido instituto (lei 1521/1951, art. $4^{\circ}$, b). Este, entretanto, é presumido, por ser o negócio jurídico de boa-fé, que atua para estabelecer o a integralidade da reparação ou da redução à eqüidade do negócio.

Na onerosidade excessiva, tal como disposta no art. 478 e seguintes do Código Civil, exige-se além do desequilíbrio contratual a imprevisibilidade. Os fatos supervenientes, além de extraordinários devem ser imprevisíveis ${ }^{31}$.

São pressupostos para a aplicação da revisão judicial por onerosidade excessiva: a) que os contratos sejam executados a prazo ou em parcelas sucessivas e periódicas; b) quando a prestação se tornar onerosa para uma das partes e vantajosa para a outra e c) a verificação de acontecimentos imprevisíveis e extraordinários, alheios à vontade dos contratantes.

Há que se atentar, contudo, que a resolução dos contratos por onerosidade excessiva tem tratamento diverso no Código Civil e no Código de Defesa do Consumidor. Basicamente, reside a diferença no fato de o instituto, no Código de Defesa do Consumidor, ensejar a revisão contratual, iluminado pelo princípio da conservação do contrato, enquanto que no Código Civil o instituto resultar na resolução.

Também em sede de direito do consumidor, a comprovação da onerosidade excessiva não se acha atrelada ao requisito da exagerada vantagem para a outra parte, ou seja, não se exige que importe em extrema vantagem para o fornecedor - como assim dispõe e prevê o Código Civil - uma vez que o CDC adotou uma postura desvinculada do enriquecimento sem causa e que, portanto, é bastante a prova de que a prestação se tornou excessivamente onerosa para o consumidor, independente desse excesso se reverter em favor do fornecedor.

No direito do consumidor, igualmente, é bastante a ocorrência de fatos

\footnotetext{
${ }^{31}$ Código Civil. art. 478. Nos contratos de execução continuada ou diferida, se a prestação de uma das partes se tornar excessivamente onerosa, com extrema vantagem para a outra, em virtude de acontecimentos extraordinários e imprevisíveis, poderá o devedor pedir a resolução do contrato. Os efeitos da sentença que a decretar retroagirão à data da citação.
}

Revista Quaestio luris, vol.04, no01. ISSN 1516-0351 p.351-423 370 
supervenientes e imprevistos após a celebração do contrato, não se fazendo necessário que esses fatos sejam também imprevisíveis e extraordinários, segundo a dicção do Código Civil, na medida em que muitas situações passíveis de previsão podem causar uma prestação absolutamente desproporcional, ou mesmo causar a qualquer dos contraentes o cumprimento de uma obrigação excessivamente onerosa, como foi o caso, por exemplo, do surto inflacionário que acometeu o país antes do Plano Real.

Para argüir a revisão no direito do consumidor não se faz necessário provar que os fatos supervenientes à contratação tenham a conotação da imprevisibilidade ou extraordinariedade exigidas pelo Código Civil de 2002, mas, sim, de revisão pura, decorrente de fatos posteriores ao pacto, independentemente de ter havido ou não previsão ou possibilidade de previsão dos acontecimentos ${ }^{32}$.

Deste modo, em apertada síntese, o Código Civil traz no seu bojo todo um novo rol de princípios sociais que implicam na substancialização de direitos e, assim, impõem uma nova consideração da eficácia das obrigações após a extinção do contrato. Como bem evidenciou a Jornada de Direito Civil promovida pelo Centro de Estudos Judiciários do Conselho da Justiça Federal, no período de 11 a 13 de setembro de 2002, sob a coordenação do Ministro Ruy Rosado, do STJ, que especificou em seu Enunciado no 25 que "O artigo 422 do Código Civil não inviabiliza a aplicação, pelo julgador, do princípio da boa-fé nas fases pré e pós-contratual". Consoante esses novos princípios sociais é que trataremos a seguir da pós-eficácia das obrigações.

2. A obrigação no sentido moderno e o surgimento da noção de pós-eficácia das obrigações

\footnotetext{
32 “REVISÃO DE CONTRATO. Arrendamento mercantil (leasing). Relação de consumo. Indexação em moeda estrangeira (dólar). Crise cambial de janeiro de 1999. Plano Real. Aplicabilidade do art. 6º, V, do CDC. Onerosidade excessiva caracterizada. Boa-fé objetiva do consumidor e direito de informação. Necessidade de prova da captação de recurso financeiro proveniente do exterior.

$\mathrm{O}$ preceito insculpido no inc. $\mathrm{V}$ do art. $6^{\circ}$ do $\mathrm{CDC}$ dispensa a prova do caráter imprevisível do fato superveniente, bastando a demonstração objetiva da excessiva onerosidade advinda para o consumidor. Resp 268.661-RJ. $3^{\text {a }}$ Turma. Superior Tribunal de Justiça. Julgado de16.08.2001. Relatora: Ministra Nancy Andrighi. DJU 24.09.2001".
} 
A obrigação no sentido moderno ${ }^{33}$ começa a se esboçar a partir da promulgação do BGB em 1900 e, sobretudo, pela nova interpretação que a doutrina e a jurisprudência alemãs passam a elaborar a partir do § 242 do BGB em face da modificação revolucionária e incessante das circunstâncias econômicas e sociais no período entreguerras.

Os arts. 157 e 242 do BGB (Bügerliches Gesetzbuch), dispunham:

\begin{abstract}
“§ 242 - O devedor está adstrito a realizar a prestação tal como o exija a boa fé, com consideração pelos costumes do tráfego ${ }^{45}$.

$\S 157$ - Os contratos interpretam-se como o exija a boa fé, com consideração pelos costumes do tráfego".
\end{abstract}

Em termos literais, o $§ 242$ nada mais representava do que o reforço do $\S 157$, no qual se determinava a regra tradicional de interpretação dos negócios jurídicos segundo a boa-fé. Não era um dispositivo posto para atribuir ao juiz a função fundamental de criar o direito, sobretudo para reduzir os rigores da aplicação do direito estrito ${ }^{34}$.

Foi com o estudo de H. Staub, Positive Vertragsverletzung, publicado em 1902, no Festschrift für das deutsche Juristentag, sobre a quebra positiva do contrato, entretanto, que se modifica o conceito tradicional de obrigação. Esta passa a ser concebida como um vínculo dialético entre devedor e credor, elementos cooperativos necessários ao correto adimplemento. A relação dialética assim estabelecida é perpassada na sua inteireza pela noção de boa-fé, que constitui, assim, uma fonte autônoma de direitos e obrigações. Sendo a relação obrigacional uma totalidade voltada para o adimplemento, esta não inclui apenas, como relação totalizante que é, o dever principal de prestar, ou um eventual dever secundário

\footnotetext{
${ }^{33}$ Diferenciando-se portanto da teoria clássica do direito civil que concebia a noção de obrigação como uma necessidade jurídica, por força da qual uma pessoa ficava subordinada em relação à outra a dar, a fazer ou não fazer alguma coisa.

A idéia de obrigação, nessa concepção, tinha uma única finalidade: a prestação, concebida como um único dever principal, seja a realização ou abstenção de um fato, seja a dação de uma coisa.

Tal concepção unívoca de obrigação tinha por fontes a lei e o contrato. A primeira era concebida como um ato assecuratório da igualdade de todos, sendo, por natureza, geral e impessoal, fruto da vontade geral . Uma dialética abstrato-geral, de um lado, e concreto-individual, do outro lado, constituía o modo específico de realização e de garantia da liberdade no Estado de Direito. Era esta dialética que proporcionava segurança à liberdade ou, numa terminologia moderna, tornava a liberdade mensurável. Concebia-se que as intervenções na liberdade e na propriedade somente poderiam ser realizadas se fundadas nesse caráter legal de generalidade e abstração. 45 Os "costumes do tráfego" [Verkehsitte], de natureza discutida, são mais do que meros usos, mas menos que Direito consuetudinário.

${ }^{34}$ SILVA, Clóvis do Couto e. O princípio da boa-fé no Direito brasileiro e português. In: FRADERA, Vera Maria Jacob de. O direito privado brasileiro na visão de Clóvis do Couto e Silva. Porto Alegre : Livraria do Advogado, 1997, p. 36-37.
}

Revista Quaestio luris, vol.04, no01. ISSN 1516-0351 p.351-423 372 
correlato, mas também deveres acessórios ou implícitos, instrumentais e independentes, ao lado da obrigação principal, todos voltados para o correto adimplemento ${ }^{35}$.

A partir da obra de H. Staub, em que se manifesta no direito germânico o conceito de quebra positiva do contrato ${ }^{48}$, marca uma nova concepção de relação obrigacional, com deveres secundários vinculados à aplicação do princípio da boa-fé. Essa transformação poderia representar apenas uma ligeira modificação do conteúdo da relação obrigacional não houvesse, simultaneamente, assumido o juiz funções criadoras do direito bem mais amplas. Essa nova posição resultou da aplicação concomitante de outro dispositivo, o $§ 138$ do Código Civil germânico, quando os tribunais começaram a declarar a nulidade de contratos em que se manifestasse a utilização abusiva do poder econômico de uma das partes, os chamados "contratos-mordaça" (Knebelungsvertrag), por serem contrários aos bons costumes (contra bonos mores) ${ }^{36}$.

Mais tarde, nos tempos da grande inflação ao redor de 1920, começou-se a falar no desaparecimento da base do negócio jurídico, outra importante criação da doutrina que se refletiu na jurisprudência ${ }^{37}$.

A relação obrigacional, sob essa nova perspectiva, passou a ser vista como uma totalidade que se encadeia e se desdobra em direção ao adimplemento, à satisfação dos interesses do credor. Como totalidade, a relação obrigacional é um sistema de processos. $\mathrm{O}$ vínculo obrigacional como um todo, muitas vezes, não se altera ou modifica com certas alterações ou modificações sofridas pelas partes. Por esse motivo, o adimplemento de um crédito determinado pode não extinguir, ou modificar, a relação jurídica.

Sob o ângulo da totalidade, o vínculo passa a ter sentido próprio, diverso do que assumiria se se tratasse de pura soma de suas partes, de um compósito de direitos, deveres e pretensões, obrigações, ações e exceções. Se o conjunto não fosse algo de orgânico, diverso dos elementos ou das partes que o formam, o desaparecimento de um desses direitos ou deveres, embora pudesse não modificar o sentido do vínculo, de algum modo alteraria a sua estrutura. Importa, no entanto, contrastar que, mesmo adimplindo o dever principal, ainda

\footnotetext{
${ }^{35}$ Ibidem, p. 37-38 48 Para uma análise completa da noção de violação positiva do contrato no direito brasileiro, ver, por todos: SILVA, Jorge Cesa Ferreira da. A boa-fé e a violação positiva do contrato. Rio de Janeiro : Renovar, 2002.

${ }_{37}^{36}$ SILVA, Clóvis do Couto e. O princípio da boa-fé no Direito brasileiro e português. op. cit., p. 38.

${ }^{37}$ Ibidem, p. 39.
}

Revista Quaestio luris, vol.04, no01. ISSN 1516-0351 p.351-423 373 
assim pode a relação jurídica perdurar como fundamento da aquisição (dever de garantir), ou em razão de outro dever secundário independente ${ }^{38}$.

Insere-se a noção de pós-eficácia das obrigações no âmbito da função integrativa da boa-fé objetiva como um dever lateral de lealdade. Deveres laterais são aqueles impostos pela boa-fé em vista do fim do contrato, mas não orientados para o interesse no cumprimento do dever principal de prestação. Caracterizam-se por uma função auxiliar da realização positiva do fim contratual e de proteção à pessoa ou aos bens da outra parte contra os riscos de danos concomitantes ${ }^{39}$.

Carlos Alberto da Mota Pinto esclarece que os deveres laterais de conduta inerentes à boa-fé são deveres funcionalizados ao fim do contrato e, como tal, surgem e se superam no desenvolvimento da situação contratual como uma totalidade, autonomizandose em relação ao dever representado pela prestação principal para assegurarem o correto implemento do escopo do contrato:

\begin{abstract}
Não existindo esses deveres desde o início, em número e com um conteúdo fixo, dependendo o seu surgimento e a sua superação da situação material concreta, como emanações do princípio da boa-fé, segundo o fim do contrato, de um fim próprio, diverso do auxílio à consecução do interesse contratual e do impedimento de conseqüências laterais indesejáveis, surgem-nos segundo a sua essência, como algo de funcional, como elementos de um processo em desenvolvimento para um determinado fim. Nesse seu papel instrumental, não estão, todavia, isolados, antes a sua funcionalidade deve ser transposta para o quadro ou sistema que, em conexão com outros elementos (créditos, débitos, direitos potestativos, deveres acessórios, sujeições, ônus), que integram: a relação contratual. Com efeito, também esta, produto de uma conexão de elementos ligados por uma comunidade de direção final, deve ser caracterizada como um processo $^{40}$.
\end{abstract}

Tendo esses deveres laterais de conduta a função de auxílio à consecução do interesse contratual, como elementos de um processo em desenvolvimento orientado para um telos, eles podem subsistir mesmo após o cumprimento da prestação principal, qual seja, o adimplemento da obrigação, como forma de assegurar que este produza todas as consequiências que poderiam ser legitimamente esperadas.

\footnotetext{
${ }^{38}$ SILVA, Clóvis do Couto e. A obrigação como processo. op. cit., p. 17-20. passim.

${ }^{39}$ PINTO, Carlos Alberto da Mota. Cessão de contrato. São Paulo : Saraiva, 1985, p. 281.

${ }^{40}$ Ibidem, p. 289. 54 LARENZ, Karl. Derecho de obligaciones. v. I. Madri : Revista de Derecho Privado, 1958, p. 156.
} 
A pós-eficácia das obrigações constitui, portanto, um dever lateral de conduta de lealdade, no sentido de que a boa-fé exige, segundo as circunstâncias, que os contratantes, depois do término da relação contratual, omitam toda conduta mediante a qual a outra parte se veria despojada ou essencialmente reduzida das vantagens oferecidas pelo contrato ${ }^{54}$. Esses deveres laterais de lealdade se consubstancializam primordialmente em deveres de reserva quanto ao contrato concluído, deveres de segredo dos fatos conhecidos em função da participação na relação contratual e deveres de garantia da fruição pela contraparte do resultado do contrato concluído.

O instituto da pós-eficácia das obrigações ou culpa post pactum finitum (c.p.p.f.) nasceu na jurisprudência alemã da década de 20. Em 26 de setembro de 1925, o Reichsgericht (RG) decidiu que depois de consumada uma cessão de créditos, o cedente continua obrigado a não tolher a posição do cessionário ${ }^{41}$. Em 3 de fevereiro de 1926, o referido Tribunal deu novo alento à essa doutrina ao prever que, expirado um contrato de edição, o titular do direito de publicação fica obrigado a não fazer novas edições antes de esgotadas as anteriores ${ }^{42}$.

A Corte Federal de Justiça - BGH (Bundesgerichtshof), instância suprema da justiça ordinária daquele país, decidiu em 1956 que num contrato de prestação de serviços, o credor da prestação de serviço que denuncia o contrato por suspeita fundamentada de

\footnotetext{
${ }^{41}$ RGZ 111 (1926), 298-305. "Da particularidade de um contrato (negócio causal) dirigido à venda de um crédito (ou de outro direito) deriva como obrigação do vendedor pela qual, para além do cumprimento imediato - através da cessão efetuada - ele ainda permanece contratualmente responsável, no âmbito do prosseguimento de uma pretensão de cedência”. apud CORDEIRO, Antonio Menezes. Da pós-eficácia das obrigações. Estudos de direito civil. v. I. Coimbra : Almedina, 1991, p. 148.

${ }^{42}$ RGZ 113 (1926), 70-78. "Este contrato foi cumprido de ambos os lados (..). Só que também depois do cumprimento, segundo o dever de lealdade derivado dos usos do tráfico dominado pela boa-fé e da própria essência do contrato de prestação de serviços podem continuar a existir vinculações. A elas pertence (..) no contrato de publicação, a vinculação do titular de não fazer concorrência ao editor". apud CORDEIRO, Antonio Menezes. Da pós-eficácia das obrigações. Estudos de direito civil. v. I. Coimbra : Almedina, 1991, p. 148. 57

NJW, 1956, p. 1513. "Afirma o tribunal que negar ao despedido, possivelmente sem culpa, em todos os casos, a possibilidade de readmissão, significaria grande iniqüidade e que esta obrigação de readmitir é um efeito ulterior do vínculo contratual (Nachwirkung), simétrico da responsabilidade pré-contratual. A persistência dum dever jurídico de adotar um certo comportamento, conforme a boa-fé, depois da própria prestação contratual, visto ser reconhecida, sempre segundo a sentença, na doutrina e na jurisprudência, mesmo para os casos de troca de mercadorias, deveria, por maioria de razão, ter lugar também na prestação de serviços, onde, aliás, a jurisprudência teria já reconhecido também deveres recíprocos de fidelidade e, do lado do credor do serviço, um dever de assegurar a subsistência da contraparte" . apud PINTO, Carlos Alberto da Mota. Cessão de contrato. São Paulo : Saraiva, 1985, p. 281
}

Revista Quaestio luris, vol.04, no01. ISSN 1516-0351 p.351-423 375 
comportamento criminoso da outra parte, se desfeita por esta a suspeita ou mesmo provada a ausência de culpa, pode ser obrigado a dar-lhe outra vez ocupação ${ }^{57}$.

O mesmo BGH (Bundesgerichtshof) decidiu de maneira análoga em 1955. Versava o caso sobre uma fábrica de casacos (de senhora) que encarregou um indivíduo, trabalhando autonomamente, de fazer um modelo segundo um desenho e, posteriormente, de fabricar uma série de casacos concebidos com base no referido desenho. Do contrato celebrado não havia qualquer cláusula de exclusividade, seja para o desenho dos modelos, seja para os casacos prontos. $\mathrm{O}$ referido indivíduo ofereceu em seguida a um concorrente daquela fábrica o mesmo modelo de casaco por ele preparado segundo o desenho. O Tribunal considerou que a venda do modelo, logo a seguir, para empresa concorrente, viola o dever de lealdade contratual, porque, segundo o princípio da boa-fé, impede a contraparte de auferir o resultado legítimo e esperado do contrato ${ }^{43}$.

Muitas outras decisões se seguiram a estas, publicadas sobretudo na revista jurídica alemã NJW (Neue Juristische Wochenschrift) e referenciadas na obra de Menezes Cordeiro $^{44}$.

Assim, na formação dos institutos jurídicos baseados na boa-fé, a pós-eficácia das obrigações ou culpa post pactum finitum derivou não de considerações doutrinárias mas, sim da necessidade judicial de solucionar questões diversas inerentes aos contratos. A sua redução dogmática, ainda longe de concitar qualquer unanimidade científica, operou, pois, posteriormente à sua consagração ${ }^{45}$.

No período posterior ao segundo conflito mundial deu-se, em certas proporções, a florescência mais significativa da culpa post pactum finitum, com primado para os estudos de Kull, de Christensen e de Kreyenberg ${ }^{46}$. Também é expressa sua manifestação nos manuais ${ }^{47}$ e nos comentários do $\mathrm{BGB}^{48}$. Na França há um relevo na doutrina, porém sem

\footnotetext{
${ }^{43}$ BGHZ 16 (1955) 4-12 (4-5). apud CORDEIRO, Antonio Menezes. Da pós-eficácia das obrigações. Estudos de direito civil. Vol. I. Coimbra : Almedina, 1991, p. 144.

${ }^{44}$ CORDEIRO, Antonio Menezes. Da boa-fé no direito civil. v. I. op. cit., p. 626-627.

${ }^{45}$ CORDEIRO, Antonio Menezes. Da boa-fé no direito civil. v. I. op. cit., p. 626.

${ }^{46}$ Bruno Kull, Die Grundlagen, Grenzen und Nachwirkungen der arbeitsrechtlichen Treu und Fürsorgepflicht (1953); Karl-Wilhelm Christensen, Verschulden nach Vertragsende! (Culpa post pactum finitum) (1958); Joachim Peter Kreyenberg, Nachwirkungen von Verträgen (1958) apud CORDEIRO, Antonio Menezes. Da boa-fé no direito civil. v. I. op. cit., p. 626.

${ }^{47}$ LARENZ, Karl. Derecho de obligaciones. v. I. op. cit., p. 156.
} 
a sistematização nas obras de caráter geral do direito civil ${ }^{49}$. No Brasil, a pós-eficácia das obrigações é expressamente admitida, dentre outros trabalhos, na obra pioneira de Clóvis do Couto e Silva ${ }^{50}$ e em diversos artigos doutrinários ${ }^{51}$.

3. A noção de relações pós-contratuais

Consideram-se relações pós-contratuais aquelas que, resultantes de um contrato, lhe sucedem de maneira independente no tempo. Assim, para que se configurem essas relações é necessário que essas sejam resultado do contrato, que o contrato já tenha terminado e que as relações lhe sejam posteriores no tempo.

A primeira questão fundamental concernente à noção de relações póscontratuais, é a de se estipular a identificação do período pós-contratual, a partir de seu elemento chave: a extinção do contrato.

\footnotetext{
${ }^{48}$ STAUDINGER, Julius von. Kommentar zum Bürgerlichen Gesetzbuch mit Einführungsgesetz und Nebengesetzen. Berlim : 1979, Weber, § 242, p. 396 ss.

${ }^{49}$ LE STANC, Christian. Existe-t-il une responsabilité postcontractuelle?, Jur.Cl.Pér. 1978, 12735 ; FONTAINE, Marcel. Les obligations « survivant au contrat » dans les contrats internationaux, D.P.C.I. 1984, p. 7 ; PETIT, F. L'après-contrat, Droit social 1995, p. 589 ; CASEAU-ROCHE, C. Les obligations postcontractuelles, Th. Paris I, 2001, dactyl. ; AMOUGUIGALOUA, P. Les obligations survivant au contrat, Th. Strasbourg, 2001, dactyl.; FONTAINE, Marcel. Les obligations « survivant au contrat ». In : COMMISSION UNIVERSITÉ-PALAIS. La fin du contrat. V. 51. Paris : CUP, 2001, pp. 159-190; VINEY, Geneviève. Introduction à la responsabilité. 3. ed. Paris: LGDJ, 2008, p. 545-546; MAZEAUD, Henri \& MAZEAUD, Leon. Traité théorique et pratique de la responsabilité civile délictuelle et contractuelle. 4. éd. T. 1. Paris: Librairie du Recueil Sirey, 1947, p. 132-134. ${ }^{50}$ SILVA, Clóvis do Couto e. Obrigação como processo. op. cit. p. 96-97

${ }^{51}$ MOTA, Mauricio. Questões de direito civil contemporâneo. Rio de Janeiro ; Elsevier, 2008, pp. 257-304; DONNINI, Rogério Ferraz. Responsabilidade pós-contratual no novo Código Civil e no Código de Defesa do Consumidor. São Paulo: Saraiva, 2004; GARCIA, Enéas Costa. Responsabilidade pré e pós-contratual à luz da boa-fé. São Paulo: Juarez de Oliveira, 2003; TREVISAN, Marco Antônio. Responsabilidade civil póscontratual. Revista de Direito Privado. São Paulo, n. 16, out-dez. 2003, p. 199-215; MELO, Diogo Leonardo Machado de. Notas sobre a responsabilidade pós-contratual. In: NANNI, Giovanni Ettore. Temas relevantes do direito civil contemporâneo. São Paulo: Atlas, 2008, pp. 400-442; AZEVEDO, Antonio Junqueira de. Responsabilidade pré-contratual no Código de defesa do consumidor: estudo comparado com a responsabilidade pré-contratual no direito comum. Revista de Direito do Consumidor $\mathrm{n}^{\circ} 18, \mathrm{p}$. 23-31, abr./jun., 1996
}

Revista Quaestio luris, vol.04, no01. ISSN 1516-0351 p.351-423 377 
Contratos são negócios jurídicos. Convenções pelas quais uma ou muitas pessoas se obrigam perante outra ou muitas outras a dar, a fazer ou a não fazer alguma coisa. São assim, via de regra, negócios jurídicos bilaterais ou plurilaterais. Os contratos são praticados por força de necessidades as mais diversas. Assim é que os contratos são fruto de uma necessidade, que impulsiona nossa vontade à satisfação dessa necessidade, seja esta real ou fictícia. A duração do contrato corresponde à duração das obrigações criadas. Enquanto as obrigações continuarem em vigor, o contrato não tem fim.

Há que se atentar, porém, para a natureza dessas obrigações. Através dos contratos satisfazemos nossas necessidades econômicas. Os contratos auxiliam no processo de circulação da riqueza. É por meio de contratos que os produtos circulam pelas várias etapas da produção: da mina à fábrica, desta à loja, e depois para as mãos do consumidor. Os contratos não só fazem circular as riquezas, mas ajudam a distribuir a renda e geram empregos. O objetivo das partes é essa operação econômica. A obrigação ou prestação correspondente a essa operação é denominada obrigação principal ou prestação característica e constitui o núcleo duro do contrato. Uma vez que esta prestação é realizada

- e, conseqüentemente, a transformação atendida pelas partes - o contrato é terminado e começa - potencialmente ao menos - o período pós-contratual. Assim, deve-se entender por duração do contrato, a duração de suas obrigações principais e características ${ }^{52}$.

Como bem lembra Antonio Junqueira de Azevedo, mesmo se uma das partes tiver aparentemente resilidido unilateralmente um contrato, mas, não obstante tal aparente decisão, continuar negociando e executando as obrigações essenciais do contrato, não há que se falar em término do contrato, mas sim em revogação tácita da denúncia por comportamento concludente e, portanto, renovação das relações contratuais por tácita recondução ${ }^{53}$. Há contrato e, assim, inexistem relações pós-contratuais.

Portanto, nessa matéria, deve-se observar uma noção estrita de duração do contrato. As relações entre as partes durante o período de eficácia dos deveres do contrato após a extinção da avença possuem características específicas que a distinguem do período

\footnotetext{
${ }^{52}$ FONTAINE, Marcel. Les obligations «survivant au contrat». In : COMMISSION UNIVERSITÉ-PALAIS. La fin du contrat. V. 51. Paris : CUP, 2001, p. 181.

${ }^{53}$ AZEVEDO, Antonio Junqueira de. Novos estudos e pareceres de direito privado. São Paulo: Saraiva, 2009, p. 159. 69 A recondução tácita do contrato foi positivada em nosso ordenamento, no contrato de seguro, pelo art. 774 do Código Civil: art. 774. A recondução tácita do contrato pelo mesmo prazo, mediante expressa cláusula contratual, não poderá operar mais de uma vez.
} 
contratual. Estas são suficientemente significativas para constituir um regime jurídico de direito próprio. Durante a fase pós-contratual, a força criativa de novas obrigações é inexistente, as limitações particulares de duração das obrigações devem ser respeitadas e os remédios contra a inexecução contratual não são aplicáveis. Estamos, portanto, em outro domínio, o das relações pós-contratuais.

Além dessa questão de determinação exata do que significa a extinção de um contrato, quando falamos de relações verdadeiramente pós-contratuais, devemos observar que existem situações exclusivas do período pós-contratual, mas que não configuram relações pós-contratuais.

Por exemplo, as situações de origem convencional. As partes acordam prosseguir a operação jurídica objeto do contrato expirado, de modo expresso. Um novo contrato intervém e exclui a qualificação do período de pós-contratual.

Do mesmo modo ocorre com a renovação ou a recondução tácita ${ }^{69}$. Há renovação tácica quando o contrato prevê uma cláusula de renovação da avença no silêncio das partes. Se as partes não se pronunciam em um certo período de tempo, um novo acordo é concluído, conforme as disposições do contrato original.

Na recondução tácita, mesmo se as partes não renovam o contrato mas, seu comportamento concludente, após a expiração da avença, permite considerar que as partes continuam a executar as obrigações contratuais essenciais como se a data da expiração do contrato não houvesse passado, há prosseguimento tácito do contrato. É o caso do contrato de prestação de serviços de rede para internet por prazo determinado. Nestes contratos o cancelamento depende do pagamento do saldo devedor do serviço, pois o usuário responde pela tarifa do serviço até o efetivo encerramento do contrato. Existindo pendências financeiras de períodos anteriores, o cancelamento definitivo dependerá da quitação dos débitos. Se nesse período, antes da quitação dos débitos e do cancelamento definitivo, o consumidor usa o serviço, estará caracterizada a continuidade da utilização do serviço e isso implicará em contrato tácito, com pagamento de novo período de uso. Há contrato tácito e, portanto, não se pode falar em relações pós-contratuais.

Da mesma maneira ocorre se situações legais impostas pela lei ou pelo juiz 
obrigam a manutenção da avença contratual. É exemplo disso o art. 1.112 do Código Civil que garante ao evicto o direito de obter o ressarcimento das despesas que teve com a realização de benfeitorias necessárias ou úteis que não lhe forem abonadas. Noutras palavras, o evicto tem direito a receber indenização por tais benfeitorias porque é possuidor de boa-fé, podendo, por isso, exercer o direito de retenção da coisa, até que seja reembolsado das despesas feitas com as benfeitorias. Não há que se considerar aqui também a existência de relações pós-contratuais.

4. Fundamentos da pós-eficácia das obrigações

A doutrina e a jurisprudência têm procurado elaborar diversos fundamentos para a pós-eficácia das obrigações. Procedamos a uma revista crítica.

a) Crítica de alguns fundamentos anteriormente propostos

O primeiro fundamento é dado, geralmente, pela consagração legal da póseficácia, a partir de diversas manifestações legais que concedem efeitos a situações obrigacionais extintas.

É o caso da revogação da procuração pelo mandante, que extingue o mandato (art. 682, I, CC), porém não pode ser oposta a terceiros que, ignorando a revogação, concluíram negócios com o mandatário (art. 686, CC). Há, por lei, pós-eficácia da procuração.

No caso de extinção do mandato por morte do mandatário, resulta para os herdeiros o dever de avisar o mandante e de tomar as providências necessárias para a consecução do negócio, até que o mandante possa atuar (art. 690 CC). Há aqui efetiva extinção do mandato e pós-eficácia legalmente consagrada.

Outro caso de pós-eficácia legal de obrigações é, no direito de família, após a 
extinção do casamento pelo divórcio, o direito de opção da mulher pela conservação do nome de casada (art. 1571, § $2^{\circ}$ do Código Civil) ${ }^{54}$. Também o pagamento de alimentos entre os cônjuges persiste mesmo após a dissolução do matrimônio, somente se extinguindo com o novo casamento ou a união estável do ex-cônjuge credor da pensão alimentícia (art. 1708 do Código Civil).

Em outro exemplo de pós-eficácia legal de obrigações o Código Civil em seu art. 1147 proíbe a concorrência após a extinção do negócio dispondo que, não havendo autorização expressa, o alienante do estabelecimento não pode fazer concorrência ao adquirente, nos 05 (cinco) anos subseqüentes à transferência.

O Código de Defesa do Consumidor abriga ainda dois dispositivos legais sobre pós-eficácia das obrigações.

O primeiro deles é o art. $10, \S 1^{\circ}$, que estabelece o dever de realizar aviso público a todo fabricante que, após a venda do produto, vem a ter ciência de algum fato que possa prejudicar o consumidor.

O segundo é o art. 32, que estabelece a obrigação de fabricantes e importadores de, cessada a fabricação ou importação do produto, continuar por período razoável de tempo, na forma da lei, a oferta de componentes ou peças de reposição.

Há também no caso do contrato de trabalho diversas leis que consagram, depois da cessação do vínculo laboral, deveres específicos a cargo das antigas partes.

Não se pode, contudo, dessas manifestações esparsas e díspares de póseficácia, estabelecer por indução um princípio geral válido para todo o espectro obrigacional. A procuração pós-eficaz é um caso clássico de tutela da confiança com base na aparência; o direito à opção do nome tem sua razão de ser em motivos próprios do direito de família; o aviso público a cargo do fabricante insere-se no âmbito dos deveres de informação contidos na idéia de lealdade contratual; o direito à reposição de peças decorre também do dever de lealdade contratual. Assim, não exsurge das diversas normas legais um fundamento comum que possa unificar o instituto jurídico da pós-eficácia das obrigações.

O segundo fundamento da culpa post pactum finitum proposto é o da analogia

\footnotetext{
${ }^{54} \mathrm{O} \S 2^{\circ}$ do art. 17 da lei $n^{\circ}$ 6515/77 estabelece: "nos demais casos, caberá à mulher a opção pela conservação do nome de casada".
}

Revista Quaestio luris, vol.04, no01. ISSN 1516-0351 p.351-423 381 
da pós-eficácia das obrigações com a culpa in contrahendo ou a responsabilidade précontratual. Deste modo, tal como existem deveres pré-contratuais, também os haveria depois de extinto o contrato.

Entretanto, como bem lembra Menezes Cordeiro, é diferente, por essência, a situação de pessoas que se encontram para contratar - e que, nessa medida, tem todas as possibilidades de se prejudicarem e, logo, o dever de não o fazer - daquela situação de pessoas que, tendo executado e extinguido contratos antes celebrados, seguem os seus rumos no espaço jurídico:

\begin{abstract}
Justifica-se a autonomização da culpa post pactum finitum porque, por um lado, a base jurídica não é já, em rigor, a mesma e, por outro lado, porque o desaparecimento da obrigação em si, ou a inexistência como possível, de um contrato futuro altera, de modo profundo, o condicionalismo de sua concretização. Basta, aliás, atinar nalgumas obrigações pós-eficazes típicas, como o dever de não concorrência ou o de fornecer assistência e sobressalentes, para registrar a especificidade da situação ${ }^{55}$.
\end{abstract}

Outro fundamento proposto, especialmente na Alemanha, a partir da década de 30, é a orientação tendente a justificar a culpa post pactum finitum com base na natureza intrínseca de certas relações jurídicas, isto é, existiriam relações jurídicas que, por natureza, produziriam efeitos depois de sua extinção.

É a idéia lançada por Willi Heil, ${ }^{56}$ de que na situação laboral nasceria uma relação comunitária entre patrão e empregado e não uma relação meramente obrigacional. Essa relação comunitária envolveria, por natureza, uma situação mútua de lealdade, com deveres conexos, que continuariam existindo após a extinção da relação de trabalho e não dependeriam nem mesmo da eventual constituição de vínculo concorrente, através da celebração de novo contrato de trabalho entre o trabalhador e entidade empregadora diferente. O vínculo laboral possuiria assim uma natureza comunitário-pessoal, fonte de alegados deveres de lealdade e assistência os quais, por natureza, seriam pós-eficazes. Encontrariam-se também relações comunitário-pessoais em outras áreas jurídicas, como o Direito de Família, a fundamentar fenômenos de pós-eficácia. Destarte, as possíveis projeções jurídicas de relações comunitário-pessoais, no que toca à pós-eficácia, importariam

\footnotetext{
${ }^{55}$ CORDEIRO, Antonio Menezes. Da boa-fé no direito civil. v. I. op. cit., p. 630.

${ }^{56}$ HEIL, Willi. Die Nachwirkungen der Treupficht des Arbeitsverhältnisses, (1937) apud. CORDEIRO, Antonio Menezes. Estudos de direito civil. Vol. I. op. cit., p. 151.
} 


\section{Quaestio Iuris}

na constituição de um status jurídico permanente não afetado, no seu todo, pela extinção, ou ainda, na formação de relações de conteúdo complexo, as quais seriam, apenas em parte, atingidas pelo fenômeno extintivo ${ }^{57}$.

A pós-eficácia configuraria-se como uma modalidade própria das relações comunitárias duradouras. Existindo vários deveres para as partes, pode ocorrer o cumprimento do dever principal evidenciando a extinção formal, subsistindo contudo deveres acessórios pós-eficazes.

Essa idéia está ligada a determinadas especificidades da responsabilidade civil alemã, eminentemente casuística, e ao esforço da sua doutrina de diferenciação de diversos aspectos que pudessem estabelecer um padrão mais genérico de vinculação jurídica. Essa doutrina, porém, não teve maior influxo fora da Alemanha, sendo atualmente hoje questionado o caráter comunitário da relação laboral ${ }^{58}$.

Assim sendo, não é possível derivar da natureza específica de supostas relações comunitário-pessoais a fundamentação de todas as manifestações de pós-eficácia das obrigações. A ocorrência de efeitos associados a situações anteriores pode ser apontada nas mais diversas áreas e a boa-fé é um princípio geral de todas as obrigações. Em todo o campo das obrigações pode-se constatar a problemática da pós-eficácia que independe portanto da natureza íntima ou específica de certas relações jurídicas.

A correta fundamentação da pós-eficácia das obrigações deve ser buscada primordialmente nos princípios da boa-fé objetiva, da função social dos contratos e do equilíbrio contratual.

b) Princípio da boa-fé objetiva

A boa-fé, como salientado anteriormente, é um princípio jurídico que informa todo o direito das obrigações, independendo sua aplicação de consagração legislativa específica $^{59}$.

\footnotetext{
${ }^{57}$ CORDEIRO, Antonio Menezes. Estudos de direito civil. Vol. I. op. cit., p. 151-152.

${ }^{58}$ Para um amplo panorama dessa teoria ver CORDEIRO, Antonio Menezes. Estudos de direito civil. v. I. op. cit., p. 160-166.

${ }^{59}$ SILVA, Clóvis do Couto. A obrigação como processo. op. cit., p. 33.
}

Revista Quaestio luris, vol.04, no01. ISSN 1516-0351 p.351-423 383 
A obrigação, informada pela boa-fé, é, assim, uma totalidade que se encadeia e se desdobra em direção ao adimplemento, à satisfação dos interesses do credor. Como totalidade, a relação obrigacional é um sistema de processos. O vínculo obrigacional como um todo, muitas vezes, não se altera ou modifica com certas alterações ou modificações sofridas pelas partes. Por esse motivo, o adimplemento de um crédito determinado pode não extinguir, ou modificar, a relação jurídica. No mesmo sentido preceitua Rogério Ferraz Donnini:

\begin{abstract}
Dessa forma, o fundamento primacial para a aplicação em nosso direito da culpa post pactum finitum está na cláusula geral de boa-fé, que propicia a flexibilização do sistema jurídico, pois a solução para situações relacionadas ao contrato que continua a produzir efeitos mesmo após o seu cumprimento e conseqüente extinção seria inviável, ou, no mínimo, de difícil aplicação num sistema jurídico sem mobilidade, inflexível, rígido, sem a existência de uma cláusula geral de boa-fét ${ }^{60}$
\end{abstract}

Há que se distinguir deveres obrigacionais e adimplemento. A distinção é de direito material e resulta muitas vezes absoluta, de sorte que o adimplemento, em tal hipótese, surge totalmente desligado da série de atos que o antecederam, estando situado em um plano diverso do adimplemento. Basta se lembrar a transmissão de propriedade no direito germânico, que é negócio jurídico abstrato.

No sistema germânico, são necessários três atos jurídicos para se transmitir um bem, nos casos de compra e venda: o contrato de compra e venda (obrigacional), o acordo de transmissão a respeito da propriedade do bem vendido (negócio jurídico efetuado no âmbito do direito das coisas) e, finalmente, o acordo de transmissão sobre o preço (também negócio jurídico do direito das coisas). A divisão dos planos do direito obrigacional (o dos deveres sucessivos em direção ao telos) e do direito das coisas (o do adimplemento), quando absoluta, significa a abstração da causa do negócio jurídico nos casos de aquisição derivada ${ }^{61}$. Isto significa dizer que, sendo o adimplemento da prestação principal passível de distinção dos deveres obrigacionais (não é o seu telos necessário, não há relação de causalidade necessária), podem subsistir deveres obrigacionais pós-eficazes, inerentes ao cumprimento da obrigação como uma totalidade.

\footnotetext{
${ }^{60}$ DONNINI, Rogério Ferraz. Responsabilidade pós-contratual no novo Código Civil e no Código de Defesa do Consumidor. São Paulo: Saraiva, 2004, p. 111.

${ }^{61}$ SILVA, Clóvis do Couto e. A obrigação como processo. op. cit., p. 43-59, passim.
} 
Sob o ângulo da totalidade, o vínculo passa a ter sentido próprio, diverso do que assumiria se se tratasse de pura soma de suas partes, de um compósito de direitos, deveres e pretensões, obrigações, ações e exceções. Se o conjunto não fosse algo de orgânico, diversos dos elementos ou das partes que o formam, o desaparecimento de um desses direitos ou deveres, embora pudesse não modificar o sentido do vínculo, de algum modo alteraria a sua estrutura. Importa, no entanto, contrastar que mesmo adimplindo o dever principal, ainda assim pode a relação jurídica perdurar como fundamento da aquisição (dever de garantir), ou em razão de outro dever secundário independente ${ }^{62}$.

Deste modo, por força do contrato estabelece-se, entre as partes, uma relação de confiança. Essa relação, derivada da boa fé, constituiria as partes em deveres mútuos, nomeadamente tendentes a não permitir defraudar a crença pacífica do parceiro contratual num decurso, sem incidentes, da relação negocial. Findo o contrato, subsiste um dever de lealdade, impondo a manutenção de determinados deveres.

Da boa-fé resulta deverem as partes lealdade à convenção livremente celebrada. A lealdade em causa traduzir-se-ia, nomeadamente, na necessidade jurídica de, para além da realização formal da prestação, providenciar a efetiva obtenção e manutenção do escopo

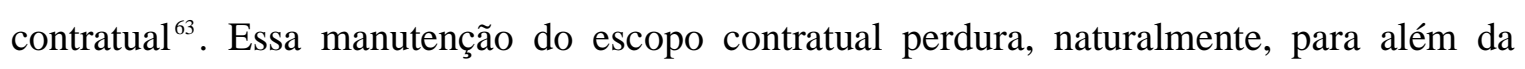
extinção do contrato em si. Há pós-eficácia ${ }^{64}$.

No direito brasileiro, como já salientado, a Jornada de Direito Civil promovida pelo Centro de Estudos Judiciários do Conselho da Justiça Federal, no período de 11 a 13 de setembro de 2002, sob a coordenação do Ministro Ruy Rosado, do STJ, consagrou essa

\footnotetext{
${ }^{62}$ SILVA, Clóvis do Couto e. A obrigação como processo. op. cit., p. 17-20. passim.

${ }^{63}$ Essa manutenção do escopo contratual se evidencia, por exemplo, na relação médica em que há um dever de confidencialidade do tratamento ministrado em determinadas situações. Inúmeros exemplos denotam a importância do segredo médico para as pessoas. Assim, podemos constatar casos de rejeição e até de exclusão social de portadores de doenças estigmatizantes e de seus familiares, como as pessoas acometidas pelo vírus HIV, cujos filhos, muitas vezes, são discriminados nas escolas. Decorre esse dever de segredo da boa-fé objetiva porque visa resguardar a intimidade da parte, de seus familiares e tem também um conteúdo público ao propiciar, por meio de difusão social, o respeito à profissão e a confiança dos cidadãos em procurarem os médicos sem receios de terem sua intimidade violada. Há ultratividade temporal ou pós-eficácia da obrigação do segredo médico porque, em decorrência da boa-fé, esta perdura, inclusive, após a morte do paciente e beneficia também a família do enfermo quando se tratar de enfermidades hereditárias ou cuja revelação possa causar constrangimento ou prejuízo de qualquer ordem. Sobre a pós-eficácia do segredo médico ver: SÁNCHEZ, Noelía de Miguel. Secreto médico, confidencialidad e información sanitária. Madrid: Marcial Pons, 2002, p. 67 e 120-121. No mesmo sentido: Abreu, Luís Vasconcelos. O segredo médico no direito português vigente, in Estudos de Direito da Bioética, Lisboa: Almedina, 2005, p. 282.

${ }^{64}$ CORDEIRO, Antonio Menezes. Estudos de direito civil. v. I. op. cit., p. 168
} 
orientação ao especificar em seu Enunciado n 25 que "O artigo 422 do Código Civil não inviabiliza a aplicação, pelo julgador, do princípio da boa-fé nas fases pré e póscontratual”.

c) Princípio da função social do contrato

A pós-eficácia das obrigações também tem fundamento na cláusula geral que estabelece a função social do contrato (art. 421 do Código Civil). A função social do contrato tem por finalidade limitar a autonomia privada, impondo um comportamento ético, comutativo, proporcional aos contraentes. Ocorre, como já dito anteriormente, uma funcionalização da liberdade contratual, diante da totalidade dos interesses sociais. A mudança de paradigma acontece porque a vontade individual não é suficiente para fundamentar a força obrigacional do contrato. A órbita de eficácia do negócio jurídico transcende - e muito - a esfera de interesses de cada parte. Há, então, uma mudança no perfil do contrato, com vistas a adaptá-lo à nova realidade social.

O princípio da função social dos contratos não será aplicável somente nos contratos cujo objeto possua abrangência coletiva, mas em toda avença na qual exista vulneração da dignidade humana (C.R.F.B., art. $1^{\circ}$, IV), sendo congênere dos princípios da função social da propriedade, da boa-fé, da vedação ao abuso do direito e do enriquecimento sem causa, todos positivados no Código Civil, os quais espelham a eticidade e socialidade que marcam profundamente o novel diploma.

O contrato é contrato segundo o uso e não segundo a substância mesma da avença. Um contrato é legítimo se está em conformidade com os limites impostos pelo bem comum, pela destinação universal, sempre anterior a qualquer uso particular. Deste modo, a função social existe, primeiramente, na comutatividade objeto do direito dos contratos, para depois se ver destacada e atingida plenamente com o exercício específico do direito de cada contrato sobre eles, conforme o estatuto legal reconheça ou não a função social deste direito.

Como esclarece Teori Zavascki ao falar da função social da propriedade (em 
tudo congênere à função social do contrato) e dispor que a noção de função de um bem significa assim um poder, mais especificamente, o poder de dar ao objeto da propriedade destino determinado, de vinculá-lo a certo objetivo:

Por função social da propriedade há de se entender o princípio que diz respeito à utilização dos bens, e não à sua titularidade jurídica, a significar que sua força normativa ocorre independentemente da específica consideração de quem detenha o título jurídico de proprietário. Os bens, no seu sentido mais amplo, as propriedades, genericamente consideradas, é que estão submetidas a uma destinação social, e não o direito de propriedade em si mesmo. Bens, propriedades são fenômenos da realidade. Direito - e, portanto, direito da propriedade - é fenômeno do mundo dos pensamentos. Utilizar bens, ou não utilizá-los, dar-lhes ou não uma destinação que atenda aos interesses sociais, representa atuar no plano real, e não no campo puramente jurídico. A função social da propriedade (que seria melhor entendida no plural, 'função social das propriedades'), realiza-se ou não, mediante atos concretos, de parte de quem efetivamente tem a disponibilidade física dos bens, ou seja, do possuidor, assim considerado no mais amplo sentido, seja ele titular do direito de propriedade ou não, seja ele detentor ou não de título jurídico a justificar sua posse ${ }^{65}$.

Vislumbra-se que toda a sociedade tem interesse em que as trocas se dêem de forma justa e que as finalidades buscadas pela relação contratual, ou seja, o interesse legítimo de ambas as partes, seja concretizado. Isso auxilia no pleno funcionamento de toda a sociedade. Nesse sentido, é na idéia de cooperação entre os contratantes, e, inclusive, entre terceiros, que se "concretiza, no direito contratual, a idéia solidarista insculpida no inciso I do art. $3^{\circ}$ da Constituição Federal" ${ }^{\prime 6}$.

Um dos grandes efeitos da idéia de função social do contrato é a funcionalização desse instituto jurídico. Ou seja, ele somente existe como tal, e com suas garantias próprias quando se destina a cumprir determinada função. Caso isso não se efetive, o instituto deve ser relativizado, e, até, as partes punidas, no intuito de buscar o bem coletivo. No campo contratual não é diferente. O contrato tem como função social dois aspectos diversos: a) ser instrumento de mercado apto a proporcionar a circulação legítima de riquezas; b) ser instrumento individual apto a proporcionar às partes a obtenção dos seus interesses legítimos. Caso um desses aspectos não seja respeitado, o contrato deve ser modificado, buscando-se a sua efetiva funcionalização.

Exemplo dessa função social do contrato nas relações pós-contratuais é a

\footnotetext{
${ }^{65}$ ZAVASCKI, Teori Albino. A tutela da posse na Constituição e no projeto do novo Código Civil. In: A reconstrução do Direito Privado. Org. Judith Martins-Costa. São Paulo : Revista dos Tribunais, 2002, p. 844.

${ }^{66}$ SILVA, Luís Renato Ferreira da. A função social do contrato no novo Código Civil e sua conexão com a solidariedade social. In. SARLET, Ingo. O Novo Código Civil e a Constituição. Livraria do Advogado, 2003, p. 132.
}

Revista Quaestio luris, vol.04, no01. ISSN 1516-0351 p.351-423 387 
ponderação entre o dever pós-eficaz de lealdade (consubstanciado na não-concorrência após o relacionamento contratual) com o direito da coletividade a que os contratos realizados pelos particulares não limitem de maneira abusiva a concorrência.

Acórdão do Tribunal de Justiça de Minas Gerais examinou interessante litígio entre a Telemig Celular S/A e uma microempresa credenciada para Loja Telemig Celular. A primeira ajuizou ação ordinária em face da segunda afirmando que celebrou com o requerido "Contrato de Credenciamento de Lojas Telemig Celular", no qual há cláusula de exclusividade que o proibia de prestar serviços, durante a vigência do contrato e até seis meses após sua cessação, a outras prestadoras de serviços de telecomunicações com atuação na mesma área de sua atuação, sob pena de multa de $10 \%$ sobre o valor do contrato.

Como este credenciado, após a extinção do contrato, mas antes do fim do prazo de seis meses, passou a oferecer ao público produtos e serviços da empresa de telefonia celular concorrente "Claro", em ofensa a cláusula de exclusividade, a TELEMIG pleiteou a condenação do réu ao pagamento da multa contratual de $10 \%$ sobre o valor do contrato, em razão do descumprimento da cláusula de exclusividade, acrescido de correção monetária e juros de $1 \%$ ao mês.

O Tribunal, entretanto, decidiu que a pós-eficácia por seis meses de cláusula contratual de não concorrência, viola a função social do contrato porque não visa garantir a outorga do resultado esperado do contrato mas sim, limitar abusivamente a concorrência, atingindo os preceitos constitucionais da livre iniciativa e concorrência (art. 170, CF) ${ }^{67}$.

Não há pós-eficácia porque inexiste o fundamento do dever de lealdade pós-

\footnotetext{
67 "In casu, é nítida a desproporção estabelecida por essa cláusula de exclusividade, com efeitos pós-contrato, haja vista que ela impede que o contratante preste serviços, por um período de seis meses após a extinção do contrato, a outra empresa de telefonia móvel, sem, contudo, estabelecer qualquer contraprestação para tanto, como, por exemplo, uma indenização.

Note-se que, segundo essa cláusula, o apelante não poderá por seis meses credenciar-se a outra operadora de telefonia celular, diminuindo, assim, a concorrência da apelada, e, em contrapartida, a paralisação das atividades do apelante, ainda mais por um período tão longo, o levará, possivelmente, senão a falência, a uma perda substancial de capital. Daí se vê que a apelada será beneficiada por essa cláusula em detrimento do apelante. Logo, não restam dúvidas que desproporcional é a obrigação estabelecida nesta cláusula, quanto ao período póscontrato, ferindo, assim, o princípio da manutenção do seu equilíbrio econômico". MINAS GERAIS. Tribunal de Justiça do Estado de Minas Gerais. Apelação no 1.0024.06.124055-2/001. Comarca de Belo Horizonte. 17 Câmara Cível. Relator: Desembargador Luciano Pinto. Julgamento em 10 de abril de 2008.
} 
eficaz (a garantia da outorga do resultado esperado do contrato) e há infração da função social do contrato. Assim, comprova-se que a função social do contrato informa também a produção de efeitos dos deveres pós-eficazes.

d) Princípio do equilíbrio contratual

O negócio jurídico, mesmo inteiramente cumprido em suas obrigações principais e características, ainda pode gerar consequiências (fase pós-negocial ou projeção de efeitos post pactum finitum). Assim, num contrato de venda de máquinas específicas e dispendiosas, mesmo sem cláusula expressa, a vendedora tem a obrigação de fornecer ao comprador as peças sobressalentes. No contrato de venda, o vendedor deve informar o comprador dos riscos da coisa, se, após cumprido o negócio, vier a ter ciência de alguma qualidade perigosa da coisa vendida. $O$ vendedor de um imóvel tem a obrigação de não prejudicar o comprador mediante alteração dos imóveis vizinhos. O técnico industrial deve manter sigilo sobre os métodos de fabricação usados na empresa em que trabalhou.

Em todas essas relações pós-contratuais, o que se exige é que embora a obrigação principal e característica já se tenha extinguido pelo adimplemento, as partes ficam obrigadas a manter o negócio bom e valioso tal qual era, dentro de um período razoável de tempo, após findo o contrato.

Foi o que decidiu na França a Cour de Cassation que determinou o efeito póscontratual a uma obrigação de não concorrência. O litígio opunha um operador de uma atividade de recuperação de dívidas e seu ex-agente. O agente tinha cortado relações com o operador e reclamava uma indenização por desvio de clientela. Em reconvenção, o operador reclamava a interdição da atividade do agente na área que lhe havia concedido. A demanda foi acolhida em primeira instância, apesar da ausência de previsão contratual de não concorrência. A Cour de Cassation negou provimento ao recurso apresentado pelo exagente. Para evitar o fundamento relativo à ausência de uma cláusula com a previsão de nãoconcorrência, o Alto Tribunal levou em consideração as circunstâncias da espécie e notadamente a falta contratual cometida pelo agente, que não restituiu o arquivo de clientela 
ao operador. A fórmula de aprovação é mesmo assim, a mais frágil entre aquelas utilizadas pela Cour de Cassation: A Corte de Apelações "colocou no encargo do Sr. Vervelle [agente] uma obrigação de não-concorrência, limitada no tempo e no espaço". Este é claramente um caso específico, fundado em considerações de eqüidade, como observaram os comentadores da decisão $0^{68}$.

Portanto, na matéria, a decisão restabeleceu o equilíbrio da relação, não permitindo que o negócio encerrado se visse fragilizado pela conduta irregular do agente posteriormente ao fim do contrato e, assim, determinando a constituição de um dever lateral de conduta de lealdade pós-eficaz de não concorrência, que decorria naturalmente do contrato extinto.

Outra expressão da noção de pós-eficácia de um dever de conduta que garante o equilíbrio contratual é aquele que diz respeito ao momento do nascimento das obrigações de efeitos pós-contratuais. Um acórdão da Cour de Cassation de 12 de fevereiro de 2002 especifica esse ponto de forma marcante. O caso dizia respeito a uma cláusula de não concorrência que, de acordo com o contrato de trabalho em causa, não é "aplicável senão se o empregador em referência expressamente a solicite por carta recomendada com aviso de recepção nos 15 dias seguintes à notificação, por uma ou outra das partes, da ruptura”.

A Câmara Social rejeitou o apelo do empregador, que se fundava na faculdade de renúncia prevista pela Convenção coletiva nacional das VRP, para contestar a nulidade da cláusula declarada pela Corte de Apelação de Paris. A decisão da Cour de Cassation merece ser reproduzida: "Mas, deve-se atentar que uma cláusula incluída em um contrato de trabalho pela qual o empregador se reserva o direito, após a rescisão do contrato de trabalho, que fixa os direitos das partes, de impor uma obrigação de não concorrência dos trabalhadores é nula; o instrumento empregado é infundado".

Isso fixa claramente que uma obrigação contratual, para ter um efeito póscontratual, deve ter nascido antes da rescisão do contrato, ou decorrer da natureza deste, sob pena de nulidade. A existência de uma faculdade de renúncia pelo empregador, que pudesse ter o mesmo resultado prático de uma cláusula prevendo efetivamente a não concorrência na

\footnotetext{
${ }^{68}$ SEIBT-FOMBART, Fabiola Oliveira. Les relations post-contractuelles. Memoire pour le Diplome d'Études Approfondis. Faculté de Droit. Université Robert Schuman de Strasbourg. Strasbourg. 2002, p. 50. Disponível em: 〈www-cde.u-strasbg.fr/da/da/AnnexesMemoires/Promo2002/seibt.pdf〉. Acesso em: 19 de outubro de 2008.
} 
extinção do contrato, é sem incidência. Isso significa que os períodos contratual e póscontratual têm uma natureza diferente ${ }^{69}$.

Se o empregador pudesse potestativamente constranger a esfera de liberdade do trabalhador, obrigando-o a um comportamento temporário de não-concorrência, fora da forma que havia sido originalmente pactuada em contrato, e após a extinção do mesmo, evidentemente tal faculdade romperia a liberdade de contratar e retiraria a igualdade da avença, coisa que o direito não pode admitir.

\footnotetext{
${ }^{69}$ idem, p. 51.
} 


\section{Quaestio Iuris}

Deste modo, é também no equilíbrio do resultado global do contrato que se fundam os deveres pós-contratuais.

5. Distinção da pós-eficácia das obrigações das figuras jurídicas afins aproximadas

Para se definir a pós-eficácia das obrigações há que se partir do conteúdo da obrigação. O vínculo obrigacional compreende, ou pode compreender, a prestação principal, prestações secundárias e deveres acessórios: a primeira relaciona-se com a atividade dominante exigida ao devedor. As segundas redundam em atuações legais ou convencionais que, funcionalmente, servem à prestação principal e que, noutras circunstâncias, poderiam integrar prestações autônomas. Os terceiros derivam, direta ou indiretamente, dos princípios sociais antes expostos e integram as adstrições necessárias à boa realização da prestação e à proteção das partes.

Deve-se ressaltar que entre esses elementos não há uma ordem necessária de relevância (prestação principal, prestações secundárias e deveres acessórios), mas sim que cada vínculo pode possuir graus diversos de intensidade. Assim, em alguns negócios jurídicos o conteúdo do negócio é formado imediatamente pelos deveres da boa-fé, como na hipótese da gestão de negócios ${ }^{70}$.

A pós-eficácia das obrigações insere-se no âmbito dos deveres acessórios de lealdade, de preservação do escopo da obrigação extinta. Contudo, antes de abordar suas peculiaridades, é necessário uma distinção prévia daquilo que não é verdadeiramente a póseficácia como:
a) pós-eficácia aparente;
b) pós-eficácia virtual e
c) eficácia continuada.

\footnotetext{
${ }^{70}$ SILVA, Clóvis do Couto e. A obrigação como processo. op. cit., p. 38.
} 
a) Pós-eficácia aparente

Os efeitos pós-eficazes de obrigações que são cominados, expressa e especificamente, por norma jurídica que tem o fato extintivo por previsão, não configuram rigorosamente pós-eficácia, mas tão-só eficácia (atual) do próprio fato extintivo que, afinal, vem a se afirmar como constitutivo de situações novas. Chama-se a esta situação, à eficácia que a lei, expressa e especificamente, associe à extinção de certas obrigações, de póseficácia aparente.

Destarte, não é caso de pós-eficácia, mas, tão-somente, de pós-eficácia aparente a revogação da procuração pelo mandante, que extingue o mandato (art. 682, I, CC), porém não pode ser oposta a terceiros que, ignorando a revogação, concluíram negócios com o mandatário (art. 686, CC).

Do mesmo modo no caso de extinção do mandato por morte do mandatário, que resulta para os herdeiros o dever de avisar o mandante e de tomar as providências necessárias para a consecução do negócio, até que o mandante possa atuar (art. 690 CC).

Outro caso de pós-eficácia aparente é o previsto no art. $473^{71}$ do Código Civil que dispõe que os contratos de distribuição por prazo indeterminado poderão ser denunciados a qualquer tempo, porém, a denúncia não poderá ser abusiva e só produzirá os efeitos que lhe são próprios, posteriormente à extinção do contrato, após o transcurso de um prazo razoável. Na prática, isso significa que o contrato continuará, após formalmente extinto pela denúncia, irradiando sua eficácia plena até o escoamento de tal prazo. As partes permanecem vinculadas ao cumprimento das obrigações avençadas e, conseqüentemente, o fabricante não poderá deixar de fornecer os bens para que o distribuidor os revenda ${ }^{72}$.

Igualmente no direito de família, quando, após a extinção do casamento pelo divórcio, existe direito de opção da mulher pela conservação do nome de casada (art. 1571,

\footnotetext{
${ }^{71}$ Código Civil. Art. 473. A resilição unilateral, nos casos em que a lei expressa ou implicitamente o permita, opera mediante denúncia notificada à outra parte.

Parágrafo único. Se, porém, dada a natureza do contrato, uma das partes houver feito investimentos consideráveis para a sua execução, a denúncia unilateral só produzirá efeito depois de transcorrido prazo compatível com a natureza e o vulto dos investimentos.

${ }^{72}$ FORGIONI, Paula Andrade. Contrato de distribuição. 2. ed. São Paulo : Revista dos Tribunais, 2008, p. 471.
} 
$\S 2^{\circ}$ do Código Civil). Também é esse o caso do pagamento de alimentos entre os cônjuges que persiste mesmo após a dissolução do matrimônio, somente se extinguindo com o novo casamento ou a união estável do ex-cônjuge credor da pensão alimentícia (art. 1708 do Código Civil).

A mesma pós-eficácia aparente ocorre em outro exemplo como o do Código Civil em seu art. 1147 que proíbe a concorrência após a extinção do negócio dispondo que, não havendo autorização expressa, o alienante do estabelecimento não pode fazer concorrência ao adquirente, nos 05 (cinco) anos subseqüentes à transferência.

Da mesma maneira constituem simples casos de pós-eficácia aparente os dispositivos albergados no Código de Defesa do Consumidor. O primeiro deles é o art. $10, \S$ $1^{\circ}$, que estabelece o dever de realizar aviso público a todo fabricante que, após a venda do produto, vem a ter ciência de algum fato que possa prejudicar o consumidor. O segundo é o art. 32, que estabelece a obrigação de fabricantes e importadores de produtos, cessada a fabricação ou importação do produto, continuar por período razoável de tempo, na forma da lei, a oferta de componentes ou peças de reposição.

b) Pós-eficácia virtual

Existem também obrigações complexas em cujo conteúdo se inscreva, desde o início, a existência de determinados deveres que, por natureza, só possam ser executados no momento imediatamente posterior ao da extinção. Aqui, a extinção em causa não é a extinção integral da obrigação mas, apenas, a da prestação principal. Nestes casos em que a eficácia da prestação secundária só se manifesta na extinção da obrigação principal, chamamos pós-eficácia virtual.

É a situação do advogado que, extinta a relação advocatícia, fica obrigado a uma prestação secundária pós-eficaz, a de devolver os documentos e papéis que houver recebido do cliente no curso da lide.

As relações suscetíveis de ligar as partes fora do período contratual são em primeiro lugar relações jurídicas. São as relações de direito entre os contratantes que sobrevivem à expiração do contrato ou pelas quais este joga um papel de termo suspensivo. 
Com efeito, ainda que o objeto do contrato já tenha sido realizado, obrigações de executar uma ou mais prestações podem restar ao encargo de uma das partes. São relações de direito que continuam a ligar os contratantes depois da extinção do contrato e sem que uma nova relação contratual as venha substituir.

Quanto mais a relação entre os contratantes foi longa e intensa, mais a separação, a expiração do contrato, será delicada de regrar ${ }^{73}$. A questão concerne, sobretudo, às operações em curso, às restituições e às destruições.

As questões das operações em curso se colocam, sobretudo, nos contratosquadro e particularmente em seu domínio de eleição, a distribuição.

Contrato-quadro (contrat-cadre) pode ser definido como aquele que busca fixar algumas das principais regras às quais se submeterão os contratos pontuais a serem futuramente celebrados pelas partes; o contrato-quadro visa criar um quadro único para governar o conjunto das relações continuadas entre os contratantes. Os contratos a serem futuramente celebrados podem ser denominados contratos de execução (contrats d'application), na medida em que concretizam o contrato-quadro. Eles "preenchem" o quadro previamente delimitado. Característica do contrato-quadro, portanto, é a vontade das partes de concluir futuros contratos de execução, submetidos a um único regime predeterminado, é a affectio modulus ou vontade de "standardização" 74 . É o caso, por exemplo, no Brasil, da pactuação do contrato de prestação de serviço de TV por assinatura (contrato-quadro) com a possibilidade de pedido pay-per-view (contrato de execução).

O mais comum na matéria é que o contrato-quadro expire quando os comandos (os contratos de execução) ainda estão em curso. Há que se discutir então, extinto o contratoquadro, o que fazer com os comandos em curso e com os estoques.

No contrato de distribuição, cabe à parte acautelar os seus interesses no período

\footnotetext{
73 "MEDIDA CAUTELAR. - Cautela inominada. - Contrato de distribuição de revistas periódicas. - Pretensão de continuidade do referido contrato pelo período não inferior a 12 meses, e ainda, o recebimento dos exemplares não vendidos e o pagamento das comissões já ajustadas. - Cabimento no caso. -Prazo de 90 dias exíguo. Existência de relação comercial entre a requerente e a requerida desde 1965. - Prorrogação do prazo determinada. - Presença do fumus boni juris e do periculum in mora. - Liminar concedida. - Recurso provido.". $1^{\circ}$ Tribunal de Alçada Cível do Estado de São Paulo. 4 Câmara Cível. A.I. 1059.583-6. Relator: Oséas Davi Viana, Julgado de 06.03.2002).

${ }^{74}$ GATSI, Jean. Le contrat-cadre. Paris : LGDJ, 1996, p. 219.
} 
pós-contratual, prevendo nas cláusulas do instrumento contratual a forma de organizar a liquidação das situações que o contrato criou entre as partes: restituição de documentos, destino dos estoques, regime dos comandos emitidos anteriormente à dissolução etc. Assim, o distribuidor que se encontra de posse de estoque do produto deverá prever em cláusula do contrato uma série de hipóteses, dentre as quais: se o produtor se obriga à compra do estoque; a permissão a esse distribuidor continuar ele mesmo a vender o estoque por um período determinado, com o saldo eventual ainda restante após a venda sendo comprado ao final pelo produtor; uma eventual obrigação de cobrir o engajamento contratual por um seguro apropriado; a previsão de garantia para problemas jurídicos decorrentes do contrato etc.

Se, não obstante, nada disso tiver sido previsto, extinta a obrigação principal do contrato de distribuição por prazo indeterminado, por resilição unilateral não abusiva, nasce para o distribuidor o dever pós-eficaz de abster-se de comercializar quaisquer produtos de seu antigo fornecedor, ainda que porventura por ele adquiridos, e de restituir ou destruir os materiais estratégicos, signos distintivos da marca e meios de publicidade específicos.

O contrato de distribuição é, via de regra, um contrato de trato continuado e por prazo indeterminado. Cabe, assim, a qualquer das partes, denunciar a qualquer tempo e sem maiores formalidades o contrato em pauta. Esse, pois, o contorno da relação negocial entre as partes que, dentro do princípio da autonomia da vontade, ajustam o contrato que pode ser objeto de resilição por quaisquer delas. Tal resilição é uma mera faculdade concedida a quaisquer das partes contraentes e cuja legitimidade de exercício repousa no direito potestativo ${ }^{75}$. Como explica Fabio Ulhoa Coelho que no contrato de distribuiçãointermediação o distribuidor não possui direitos além dos especificamente negociados com o distribuído:

"Essa delimitação tem especial importância no momento da resolução do vínculo
contratual. Com efeito, os contratantes articularam suas empresas numa colaboração
voltada à formação de um mercado. Uma vez rompido o vínculo, o distribuído
provavelmente continuará operando nesse mercado, direta ou indiretamente, mas o
distribuidor poderá ser excluído. É o que ocorre na hipótese de o fornecedor, após o

75 "presume a lei que as partes não quiseram se obrigar perpetuamente e portanto que reservaram a faculdade de resilir o contrato a qualquer tempo. O fundamento do poder de resilir é no caso a vontade presumida das partes ...A natureza do poder de resilir unilateralmente o contrato não sofre contestação. Trata-se de um direito potestativo... Não fosse assegurado o poder de resilir e, por certo, seria impossível ao contratante libertar-se do vínculo quando o outro não concordasse. Sua função é importante, pois que permite a liberação.." GOMES, Orlando. Contratos. Rio de Janeiro : Forense, 1966, p. 187-188. 
encerramento do prazo contratual, contratar nova distribuição-intermediação com terceiro, estipulando cláusula de territorialidade abrangente da área de atuação do antigo colaborador. Este último não poderá mais lucrar com o mercado que ajudou a constituir.

Como não há disciplina legal do contrato de distribuiçâo-intermediação, o distribuidor deve buscar a proteção aos seus interesses no plano negocial, ajustando as expectativas de retorno às cláusulas que conseguir negociar com o distribuído.

Em outros termos, se o contrato de distribuição-intermediação é celebrado com prazo determinado, o distribuidor deve praticar preço que lhe possa proporcionar a amortização dos investimentos e a margem de lucro desejada no período de duração do vínculo, já que não tem garantia de continuar explorando o mercado daquele produto para além desse tempo..." ${ }^{16}$.

Os investimentos efetuados pelo distribuidor no negócio se inserem em suas próprias expectativas de lucro, tendo-se em vista, justamente a operacionalização de suas atividades. Tais investimentos são, pois, ínsitos à sua atividade comercial e não podem deste modo ser objeto de indenização. Tem ele o simples dever pós-eficaz de abster-se de comercializar os produtos, ainda que porventura por ele adquiridos (já que nada mais lhe é devido, a qualquer título), e de restituir ou destruir os materiais estratégicos, signos distintivos da marca e meios de publicidade específicos ${ }^{77}$.

Sendo os deveres pós-eficazes, nessas hipóteses, meros sucedâneos da realização da obrigação principal, não há verdadeiramente pós-eficácia, mas tão somente a chamada pós-eficácia virtual.

c) Eficácia continuada

Existe também um gênero de obrigações complexas no qual se manifestam ao longo do curso da obrigação tanto o dever de prestar principal quanto os deveres secundários. Ocorre, então, a extinção do dever de prestar principal, continuando devidos os demais elementos até o seu cumprimento integral.

É o caso, por exemplo, de um banqueiro que, tendo realizado a venda de seu

\footnotetext{
${ }^{76}$ COELHO, Fábio Ulhoa. Curso de Direito Comercial. V. 3. 5. ed. São Paulo: Saraiva, 2005, p. 105.

77 “SÃO PAULO. Tribunal de Justiça do Estado de São Paulo. Apelação n o 1067.549-9. 24 Câmara de Direito Privado. Relator: Desembargador Cardoso Neto. Julgamento em 28 de junho de 2007. Contrato verbal de distribuição de bebidas. Autora que figurou como distribuidora. Ré que proíbe a demandante de retirar mercadorias de sua fábrica. Alegação da autora no sentido de abuso de poder econômico. Autora que imputa à ré a prática de tal abuso e a culpa pela rescisão do contrato. Ação declaratória e de indenização. Inaplicabilidade da lei n. 6729, de 28 de novembro de 1979. Caso de resilição que confere a ambas as partes o direito de por fim ao ajuste. Sentença de improcedência confirmada. Recurso da autora desprovido. Preliminares de nulidade da r. sentença repelidas. Agravo retido desprovido. Inconsistência das alegações. Recurso parcialmente provido para supressão da condenação em litigância de má fé”.
} 


\section{Quaestio Iuris}

banco, fica obrigado por cláusula contratual (prestação secundária) a não montar novo estabelecimento na área financeira pelo prazo de três anos ${ }^{94}$.

Segundo Menezes Cordeiro, é correto integrar a eficácia continuada na póseficácia em sentido amplo: executada a prestação principal - e sem prejuízo da unidade da obrigação - algo muda; realizada a prestação principal genérica, opera-se a concentração, com a inversão de risco conexa. Subsistem, porém, com a prestação secundária, os deveres acessórios a ela inerentes. E os elementos que continuam são, de alguma forma, posteriores à parte já realizada ${ }^{95}$.

A eficácia continuada das obrigações e sua posteridade em relação à prestação principal recebeu expresso reconhecimento doutrinário no artigo 7.3.5 da sistematização dos princípios do direito internacional das obrigações, o UNIDROIT:

“Artigo 7.3.5 - Efeito geral da resolução

(1) A resolução do contrato libera para o futuro ambas as partes da respectiva obrigação de efetuar e de receber a prestação.

(2) A resolução não exclue o direito ao ressarcimento do dano pelo inadimplemento.

(3) (3) A resolução não tem efeito sobre cláusula do contrato relativa à composição da controvérsia ou sobre qualquer outra cláusula do contrato que deva ser operativa até depois da resolução" (tradução livre).

\section{A pós-eficácia das obrigações stricto sensu}

A pós-eficácia das obrigações stricto sensu tem seu cerne constituído pelos deveres acessórios. Decorrem estes da boa-fé objetiva e de suas concretizações, da função social dos contratos e do equilíbrio contratual, como examinado anteriormente. Distinguemse da eficácia aparente ou atual de obrigações extintas por não serem prescritos por disposição legal expressa e específica e diferenciam-se das prestações secundárias porque não constam diretamente da fonte da obrigação-mãe, para vigorarem depois da extinção da obrigação principal.

Menezes Cordeiro salienta com proficiência o fundamento da persistência de tais deveres acessórios: 
A idéia da sobrevivência dos deveres acessórios é a de que ao Direito repugna que o sentido das obrigações seja desvirtuado por cumprimentos vazios ou outras fórmulas chicaneiras ou a que, a coberto das obrigações, sejam infligidos danos às partes. Se, depois da extinção das obrigações, mas mercê das circunstâncias por ela criadas, surgirem ou se mantiverem condições que, na sua vigência, podem motivar a constituição de deveres acessórios, eles mantêm-se. As razões de busca de saídas jurídicas materiais que levam, independentemente da vontade das partes, a admitir deveres acessórios durante a vigência da obrigação são sobejamente fortes para os impôr, depois da extinção ${ }^{78}$.

A pós-eficácia das obrigações constitui um dever acessório de conduta, no sentido de que a boa-fé exige, segundo as circunstâncias, que os contratantes, depois do término da relação contratual, omitam toda conduta mediante a qual a outra parte se veria despojada ou essencialmente reduzidas as vantagens oferecidas pelo contrato ${ }^{79}$. Esses deveres acessórios se consubstanciam primordialmente em deveres de reserva quanto ao contrato concluído, dever de segredo dos fatos conhecidos em função da participação na relação contratual e deveres de garantia da fruição pela contraparte do resultado do contrato concluído.

Estes deveres acessórios são distintos da eficácia continuada porque na vigência da obrigação estes deveres inscrevem-se em seu conteúdo, sem autonomia própria. Ora se concretizam num sentido, ora no outro, conforme o desenrolar dos acontecimentos. A sua violação leva ao mau cumprimento do dever de prestar. Contudo, a manifestação de deveres acessórios sem o dever de prestar propriamente dito confere-lhes uma finalidade diferente: tornam-se verdadeiras obrigações legais independentes. $\mathrm{Na}$ autonomia que surge apenas depois da extinção da obrigação propriamente dita, está o traço distintivo dos deveres pós-eficazes em sentido próprio ${ }^{80}$.

Consistem esses deveres acessórios autonomizados uma relação de lealdade decorrente da boa-fé e da função social dos contratos. Extinta a obrigação pelo adimplemento do dever principal não há mais que se falar em deveres de indicação e de esclarecimento ou deveres de proteção.

O dever de esclarecimento, como o seu nome indica, dirige-se ao outro

\footnotetext{
${ }^{78}$ CORDEIRO, Antonio Menezes. Estudos de direito civil. v. 1. op. cit., p. 181.

${ }^{79}$ LARENZ, Karl. Derecho de obligaciones. v. 1. op. cit. p. 156.

${ }^{80}$ CORDEIRO, Antonio Menezes. Estudos de direito civil. v. 1. op. cit., p. $182 .{ }^{99}$

SILVA, Clóvis do Couto. A obrigação como processo. op. cit., p. 94.
} 
participante da relação jurídica, para tornar clara certa circunstância de que a contraparte tem conhecimento imperfeito, errôneo, ou ainda ignora totalmente. Esclarecimento, evidentemente, relacionado com alguma circunstância relevante. Não se trata de dever para consigo mesmo, mas em favor do outro ${ }^{99}$. Com a extinção da obrigação, não há mais a alteridade, o dever para com o outro. O dever de informação, de reserva ou de sigilo não se destina mais a assegurar a correta execução da obrigação existente e sim transmuda-se numa relação de lealdade para com a obrigação já extinta como uma totalidade: é no interesse de assegurar seu resultado, seu telos, que o dever existe. Configura-se, portanto, num dever de lealdade, de garantia do escopo do contrato.

Como ficou caracterizado em decisão de 02 de junho de 1993 da $1^{\text {a }}$ Câmara Cível da Cour de Cassation, na França. Tratava a decisão da obrigação de segredo do banqueiro, que sobrevive à extinção do contrato, apesar da ausência de cláusula contratual com essa previsão. O caso consistia em objetos e tábua de valores, provenientes da Galeria Vollard, que haviam sido depositados por um estudante iugoslavo na Société Générale. O contrato de guarda foi resilido em 1946, após o desaparecimento do estudante durante a Segunda Guerra Mundial. Os herdeiros do diretor da Galeria ajuizaram ação contra o Banco por não ter feito conhecer aos sucessores do desaparecido a existência de objetos suscetíveis de lhes pertencer. A Corte rejeitou o recurso porque "a obrigação de segredo à qual está jungido o banqueiro não cessa com a resilição do contrato de guarda concluído com seu cliente" ${ }^{81}$. Assim, pode-se concluir que o dever de sigilo não se destina mais a assegurar a execução da obrigação contratual anterior (senão os sucessores do desaparecido teriam sido avisados), mas sim garantir o escopo do negócio.

O mesmo ocorre com a noção de deveres de proteção. Destinam-se estes à proteção e ao cuidado com a pessoa e o patrimônio da contraparte na relação obrigacional. Pressupõem, como os anteriores, a alteridade. Ora, extinta a obrigação, pelo adimplemento, o que permanece é o seu telos, a garantia do resultado do contrato, e não mais deveres para com a contraparte. Resplandece apenas o dever de lealdade para com a obrigação em sua totalidade ${ }^{82}$.

\footnotetext{
${ }^{81}$ SEIBT-FOMBART, Fabiola Oliveira. op. cit., p. 50.

${ }^{82}$ SÃO PAULO. $1^{\circ}$ Tribunal de Alçada Cível do Estado de São Paulo. Apelação no 770.726-4. Comarca de Santos12a Câmara. Relator: Juiz Campos Mello. Julgamento em 16 de abril de 1998. "E as perdas e danos são
} 
Assim, não assiste razão nesse ponto a Menezes Cordeiro quando propugna que na fundamentação da culpa post pactum finitum estão os deveres de confiança, lealdade e proteção $^{83}$. O dever de não defraudar a crença pacífica num decurso, sem incidentes, da relação contratual, que o autor fundamenta como dever de confiança, é elemento da execução do contrato, mas não já incidente no período pós-contratual. Neste, rompida a alteridade e restabelecida a liberdade negocial das partes, a confiança não é mais elemento necessário, subsistindo tão-somente o dever de lealdade.

Do mesmo modo ocorre com o dever de proteção. Menezes Cordeiro defende a idéia de que, findo o contrato, as antigas partes não ficam logo, entre si, na situação de meros estranhos de deveres de proteção, subsistindo um dever mais forte que o simples neminem laedere $^{84}$. Todavia, com a extinção da obrigação pelo adimplemento, rompe-se o vínculo e restaura-se a liberdade negocial. Não há que se falar mais em alteridade, em dever para com o outro, mas sim em vínculo de natureza diversa, de lealdade para com a obrigação como um todo.

Esclarecida a questão do dever inerente à pós-eficácia das obrigações, dever acessório ou lateral de lealdade, decorrente da concretização da boa-fé objetiva, cabe discorrer sobre o problema da sua exata determinação. Tais deveres, como explicitado anteriormente, são autônomos em relação à obrigação de prestar principal, não resultando constitutivamente dela (como a pós-eficácia virtual), nem diretamente ex lege.

A determinação se o implemento de uma determinada conduta constitui ou não

\begin{abstract}
inequivocamente devidos. Hoje em dia, a boa doutrina admite que o dano ao patrimônio do outro contratante pode ocorrer não apenas in contrahendo, na vigência do contrato, mas também post pactum finitum, gerando também o dever de indenizar" (cf. Antônio Menezes Cordeiro, "Da pós-eficácia das obrigações", Coimbra: Almedina, p. 56). Não fora por isso, há em nosso ordenamento previsão expressa do dever de compor os danos decorrentes do inadimplemento.

Na espécie, o arbitramento dessas perdas e danos deve levar em conta as circunstâncias da normalidade da avença. Se a ré fez instalar seis recipientes de transporte nos caminhões da autora, a presunção que deve incidir é no sentido de que pelo menos uma viagem diária deveria ser realizada por cada caminhão. Assim, ela deverá pagar à apelante quantia equivalente a 36 viagens semanais por período de 3 meses, que deveria ser o prazo transcorrido entre a denúncia e a extinção do vinculo. Portanto, a ré deverá pagar à autora importância equivalente a 432 viagens, ao preço de $\mathrm{R} \$ 180,00$ cada uma, que é o preço do frete que foi afirmado na inicial e que não foi impugnado na resposta, perfazendo o montante de $\mathrm{R} \$ 77.760$, 00, que deverá ser atualizado a partir de junho de 1994 e acrescido de juros de mora, contados da citação.

${ }^{83}$ CORDEIRO, Antonio Menezes. Estudos de direito civil. Vol. 1. op. cit., p. 168-169.

${ }^{84}$ CORDEIRO, Antonio Menezes. Estudos de direito civil. Vol. 1. op. cit., p. 169.
\end{abstract}


um dever acessório da obrigação extinta deve ser buscada na função integrativa da boa-fé objetiva (art. 422 do Código Civil), nas regras da base do negócio jurídico e na função social e econômica do negócio avençado (art. 421 do Código Civil).

Na conhecida definição de Larenz, deve-se entender por base objetiva do negócio jurídico as circunstâncias e o estado geral das coisas cuja existência ou subsistência é objetivamente necessária para que o contrato subsista, segundo o significado das intenções de ambos os contratantes, como regulação dotada de sentido ${ }^{85}$. Esclarece este que a finalidade do contrato é a objetividade ínsita na natureza do próprio contrato ou aquela ulterior de uma das partes, que ambos os contratantes tenham tido em conta ao determinar o conteúdo do contrato.

Observa-se isso na proibição de não-concorrência. Embora o art. 1147 do Código Civil tenha estabelecido que não havendo autorização expressa, o alienante do estabelecimento não pode fazer concorrência ao adquirente, nos cinco anos subseqüentes à transferência, não estabeleceu o referido dispositivo um limite geográfico, mas este se infere pela função integrativa da boa-fé, com a constituição dos deveres acessórios, e pela função social do negócio.

A venda do estabelecimento como entidade unitária compreende todos os elementos que o integram principal ou acessoriamente. Abrange o aviamento, a clientela, o material, os utensílios, as máquinas, as mercadorias, as marcas de comércio, salvo estipulação expressa em contrário. Assim, o alienante tem a obrigação de fazer boa ao adquirente a coisa vendida, o que acarreta a proibição de se estabelecer no mesmo ramo. As cláusulas de não-concorrência, no trepasse, têm sido reconhecidas como válidas pelo princípio da boa-fé objetiva, sempre que necessárias à eficácia do contrato e quando limitadas no tempo e no espaço, como uma prática comercial legítima.

Assim, pressupõe-se sempre, consoante a função integrativa da boa-fé, quanto à limitação geográfica da cláusula de não-concorrência, que a cláusula deve ser limitada à zona em que o vendedor tinha introduzido os seus produtos ou serviços antes da operação ${ }^{86}$.

\footnotetext{
${ }^{85}$ LARENZ, Karl. Base del negocio juridico y cumplimiento de los contratos. Madri : Revista de Derecho Privado, 1956, p. 170.

86 “CONCORRÊNCIA DESLEAL - VENDA DE ESTABELECIMENTO COMERCIAL - ABERTURA DE NOVO NEGÓCIO - COMPROMISSO EXPRESSO DO VENDEDOR). Ao vendedor não é lícito, sem
} 
A análise funcionalizada da validade da proibição de concorrência no contrato de trespasse deve levar em conta a tutela das legítimas expectativas do adquirente em conformidade com a função social e econômica do contrato de trespasse e de acordo com as tratativas estabelecidas pelas partes durante a fase de negociação. Deve considerar também, objetivamente, a preservação do equilíbrio do mercado, sob pena de causar um impacto negativo, como o exercício abusivo de posição dominante, por limitar ou impedir o acesso legítimo dos adquirentes ao mercado. Deste modo, há a pós-eficácia do dever de lealdade do vendedor do estabelecimento de não se restabelecer no mesmo ramo de negócio na mesma área geográfica do estabelecimento trespassado, dever esse que se infere de uma construção axiológica dos valores do tecido normativo brasileiro, a saber, os princípios da boa-fé (art. 422 do Código Civil) e da função social e econômica do contrato (art. 421 do Código Civil) ${ }^{87}$.

Através da noção de base objetiva do negócio jurídico é possível mesmo delimitar que tal dever secundário pós-eficaz de lealdade é extensível a outras relações jurídicas não expressamente referidas na doutrina. Constitui a base objetiva do negócio jurídico, por exemplo, na compra e venda de um estabelecimento, o uso regular da coisa segundo sua utilidade e a livre disposição da mesma (a finalidade insíta do contrato). Ou ainda, na compra e venda de um vestido de noiva, para ser usado na cerimônia do matrimônio (finalidade ulterior de uma das partes), o fato de que este deve ser entregue antes da referida cerimônia (uma vez que, a outra parte teve tal finalidade em conta ao determinar o conteúdo do contrato).

Um contrato não pode subsistir como regulação dotada de sentido quando:

a) a relação de equivalência entre prestação e contraprestação que nele se pressupõe, se tenha destruído em tal medida que não se possa falar em prestação e contraprestação e

autorização do comprador, fundar estabelecimento em que lhe fosse retirar toda ou parte da clientela. Essa turbação por parte do vendedor importaria privar o comprador no todo ou em parte da coisa vendida. Não há, em face do que determina o art. 214 do Cód. Comercial, necessidade de estipulação formal, expressa pela qual o vendedor se obrigue a não se estabelecer". (RT 167/237).

${ }^{87}$ GRECHI, Frederico Price. A cláusula de não concorrência na cessão do estabelecimento empresarial na perspectiva civil-constitucional. In: GAMA, Guilherme Calmon Nogueira da \& ALVES, Alexandre Ferreira de Assumpção. Temas de Direito civil-empresarial. Rio de Janeiro : Renovar, 2008, p. 362.

Revista Quaestio luris, vol.04, no01. ISSN 1516-0351 p.351-423 403 
b) a finalidade objetiva do contrato, expressa em seu conteúdo, tenha resultado inalcançável, ainda quando a prestação do devedor seja possível ${ }^{88}$.

Fixados esses parâmetros, existirá um dever lateral ou acessório, pós-eficaz em relação ao dever principal e não uma conduta indiferente ao negócio jurídico realizado, sempre que a atitude de uma das partes contrariar, em infringência à boa-fé objetiva, a base objetiva do negócio. Assim, a conduta de uma das partes que revela detalhes sobre um negócio que, na concepção comum das partes quando ultimaram o mesmo e ínsita à natureza da avença, deveriam permanecer fora do conhecimento de terceiros (ex: o preço e as condições de venda de um conglomerado bancário), configura uma violação do dever de lealdade. Por outro lado, a constituição pelo vendedor de nova sociedade em ramo diverso do financeiro, seria um comportamento indiferente à compra e venda realizada, porque não contraria em nada a base do negócio jurídico.

Desse modo, embora o contrato de trespasse não se confunda estruturalmente com o contrato de alienação de quotas ou ações, quando existir a mesma base do negócio jurídico, ou seja, no caso da alienação de quotas ou de ações representativas do poder de controle da sociedade empresária, em que o objeto é a própria sociedade empresária que se realiza por intermédio da transferência da titularidade das quotas, tendo em vista certas circunstâncias (ex. conhecimento das características organizativas da empresa, relações pessoais com fornecedores, financiadores e clientes, etc. ${ }^{89}$, há do mesmo modo, dever pós-

\footnotetext{
${ }^{88}$ LARENZ, Karl. Base del negocio juridico y cumplimiento de los contratos. op. cit. p. 170.

${ }^{89}$ COMPARATO, Fábio Konder. A Cessão de Controle Acionário é negócio mercantil? Revista Forense, n. 273 , an. 77, jan - mar. 1981, p. 41. 109 SÃO PAULO. $1^{\text {o }}$ Tribunal de Justiça do Estado de São Paulo. $6^{\text {a }}$ Câmara de Direito Privado. Agravo de Instrumento no 277.006-4/9-00. Relator: Desembargador Sebastião Amorim. Julgamento em 06 de fevereiro de 2003. "EMENTA: Ação de Abstenção de Atividade Comercial e Indenização. Decisão que concedeu a tutela antecipada. Manutenção com base nas provas já existentes nos autos. Cessão na qual está implícito que a recorrente não poderá exercer o mesmo ramo de comércio da referida sociedade comercial. Recurso Improvido. [...] Silvana Regina Mirisola Soda, por seus advogados, irresignada com a r. decisão que concedeu a tutela antecipada formulada nos autos da 'Ação de Abstenção de Atividade Comercial e Indenização’, ajuizada por Vero Verdi Comércio e Paisagismos Ltda., contra ela se insurge postulando a sua reforma. Informa a agravante, inicialmente, em breve síntese, que a agravada alega que adquiriu as quotas da sociedade à qual pertencia e que, pelo preço pago, adquiriu também a clientela, motivo pelo qual estaria impedida de exercer a atividade de paisagista. Sustenta, portanto, o desacerto do entendimento esposado no decisum guerreado, eis que o mesmo não está amparado por fundamento legal, ferindo o direito elementar de exercer suas atividades profissionais livremente, o que não pode subsistir. Afirma que a transação comercial, nos termos do documento que junta a este recurso, abrangeu, única e exclusivamente, o patrimônio do estabelecimento, não havendo conseqüentemente qualquer menção sobre a proibição ou renúncia, que deveria
} 
eficaz de lealdade do alienante de não fazer concorrência ao adquirente, isto é, de não lhe desviar, dificultar ou retirar a clientela ${ }^{109}$.

O padrão de conduta exigível depois do término da relação obrigacional é o do bonus pater familias, entendido este como o homem razoável em toda a sua dimensão. Homem razoável é aquele que não só age com toda diligência devida e oportuna, mas também, baseado nos juízos de experiência e razoabilidade intersubjetiva.

Não cabe exigir apenas uma conduta meramente diligente, mas sim uma conduta diligente fundada nos juízos de experiência (do que ordinariamente acontece) e razoabilidade (proporcionalidade e moderação). Destarte, se um banqueiro vende sua participação acionária majoritária num complexo financeiro e industrial e, conservando participações acionárias nesse mesmo complexo, logo após a venda, começa a alienar suas participações minoritárias açodadamente a terceiros, existe uma violação do dever acessório de lealdade para com o negócio realizado. Sua conduta desarrazoada faz pressupor ao mercado que o negócio vendido não goza de boa saúde financeira.

Registre-se que a determinação dos deveres acessórios de lealdade não é, portanto, um rígido estalão que se pode fixar de maneira peremptória, mas sim uma pauta diretiva a ser necessariamente fixada pelo juiz. É este que irá determinar quando uma variação quantitativa de atitudes determinará uma mudança qualitativa que implicará na violação do dever acessório de lealdade" ${ }^{90}$.

Portanto, partindo-se do pressuposto que a base do negócio deve ser reconhecível por ambas as partes, no seu significado fundamental, deve-se perguntar: teria a pessoa que aciona a contraparte, para cumprimento de um dever pós-eficaz singular, alçado esse ponto particular à categoria de condição do contrato se, na sua conclusão, tivesse conhecido a situação no fim ocorrida? E, além disso, teria, em tal eventualidade, a contraparte, de aceitar tal vinculação? Como bem salienta Menezes Cordeiro, interessa

\footnotetext{
ser expressa, da ora recorrente de atuar [...]. Quanto ao mérito, porém, melhor sorte não socorre a agravante, pelo que improcedem as suas razões recursais. Com efeito, Silvana Regina Mirisola Soda cedeu suas quotas sociais que possuía na empresa Vero Verdi Comércio e Paisagismos Ltda., nova denominação da empresa 'SS Comércio e Paisagismo Ltda. ME’ e, em sendo assim, está implícito, nessa cessão que não poderá exercer o mesmo ramo de comércio da referida sociedade comercial".

${ }^{90}$ LARENZ, Karl. Base del negocio juridico y cumplimiento de los contratos. op. cit. p. 144-145. ${ }^{111}$ CORDEIRO, Antonio Menezes. Estudos de direito civil. v. I. op. cit., p. 185.
} 
apurar se, à luz dos critérios de moralidade e colaboração, na consideração da situação das partes, o dever se impõe ou não, depois da extinção do dever principal, e tendo em conta o tipo de contrato em causa ${ }^{111}$.

7. O regime jurídico da pós-eficácia das obrigações

Uma questão também assaz relevante nessa matéria é a de se determinar se o dever acessório de lealdade da pós-eficácia das obrigações configura uma situação de responsabilidade contratual ou aquiliana, bem como o regime das vinculações jurídicas (contratual ou aquiliano) dele decorrentes.

O contrato, como negócio que é, realiza a liberdade de autodeterminação da pessoa mediante a estatuição de conseqüências jurídicas. Pelo contrato, no exercício da autonomia privada, cada contratante através de declaração de vontade, expressa ou tácita, que corresponde em conteúdo à declaração do outro contratante, dá a conhecer ao outro sua vontade de que o disposto na convenção deva ter entre eles vigência e ser direito. Posto que o contrato só vale quando ambos contratantes consentem e, portanto, suas declarações coincidem em seu conteúdo, a vinculação de cada contratante ao contrato repousa em sua própria vontade, em sua autodeterminação. Vincula-se porque sabe que só sob este pressuposto o outro se vincula também e pode confiar no que é prometido. A conclusão de um contrato é assim um ato de autodeterminação através de uma autovinculação ${ }^{91}$.

Deste modo, é a autovinculação expressa no acordo de vontades que constitui os contratantes em obrigações jurídicas, limitando a sua liberdade. As declarações de vontade expressam o limite a partir do qual já não há exercício da autodeterminação negocial. Uma vontade que não ultrapassou a interioridade do agente não é relevante, ao passo em que uma declaração que não corporifique uma vontade conformadora não é fruto desta. Por outro lado a relação contratual, como visto acima, constitui uma conexão de elementos (créditos,

\footnotetext{
${ }^{91}$ LARENZ, Karl. Derecho justo: fundamentos de etica juridica. Madri : Civitas, 1993, p. $67 .{ }^{113}$ CORDEIRO, Antonio Menezes. Da boa-fé no direito civil. v. 1. op. cit., p. 640 e ss.
} 
débitos, direitos potestativos, deveres acessórios, sujeições, ônus), ligados por uma comunidade de direção final, que deve ser caracterizada como um processo, como um programa contratual

Os deveres laterais de conduta corporificam esse programa contratual ou não, ou, dito de outra forma, eles são de natureza contratual ou delitual?

Posição importante é a de Menezes Cordeiro, para quem os deveres laterais, ressalvados os casos em que a proteção da esfera pessoal e patrimonial da parte advém de estipulações contratuais estabelecidas, têm natureza delitual porque não há como vislumbrar no contrato deveres não previstos pelas partes, objetivando a tutela de interesses neutros em relação aos objetivos da relação negocial ${ }^{113}$.

Assim, para o mencionado autor, os deveres de proteção têm por objetivo assegurar que os participantes de relações obrigacionais não se inflijam danos mútuos à esfera pessoal e patrimonial de cada um, âmbito em que, para o autor, extrapola em muito os interesses obrigacionais. O mesmo pode-se dizer quanto aos deveres laterais de informação e lealdade, cuja natureza legal encontra fundamento no princípio da boa-fé. Seja na fase pré-contratual, durante a vigência ou após a extinção do contrato, tais deveres jamais poderiam ser considerados como oriundos da vontade humana, impondo-se, pois, a aceitação de que a responsabilidade oriunda de suas violações é de ordem delitual ${ }^{92}$.

Igualmente, Manuel Carneiro da Frada conceitua que, fora das hipóteses de declarações expressas ou tácitas de vontade, não há como atribuir ao acordo de vontades, a causalidade da estatuição de outros deveres, como os deveres laterais ou acessórios de conduta.

Para este autor, a própria declaração tácita permitiria visualizar essa concepção porque, baseando-se em comportamento que não visa em primeira linha à exteriorização de uma vontade negocial, permite, contudo, lateralmente concluir pela presença dessa vontade. Tal declaração, mesmo em suas formulações mais objetivas, exigiria pelo menos a consciência da emissão da declaração. Se ela não existisse, estaríamos no campo dos simples comportamentos juridicamente relevantes ${ }^{93}$.

\footnotetext{
${ }^{92}$ CORDEIRO, Antonio Menezes. Da boa-fé no direito civil. v. 1. op. cit., p. 640 e ss.

${ }^{93}$ FRADA, Manuel A. Carneiro da. Contrato de deveres e protecção. Coimbra : Coimbra, 1994. p. 68-69.
} 
Só por pura ficção, para Carneiro da Frada, pode-se admitir que as partes reconheçam, no momento do acordo, e declarem instituídos tais deveres, com vistas à preservação de bens patrimoniais ou pessoais já subsistentes em sua esfera jurídica, já que, as declarações que conscientemente emitem, visam antes ao estabelecimento da relação de prestação. Para ele, só apoiando-se em estatutos abstratos como o apelo ao contrato, ou, mais explicitamente ao seu sentido, sem apoio direto nas declarações correspondentes, se poderia falar numa fundamentação contratual dos deveres laterais de conduta. Acrescenta ainda que essas posições só logram justificar-se como contratualistas, abandonando o princípio da autonomia privada e fundamentando o contrato numa noção objetivada, identificando-o com um comportamento jurídico relevante, capaz de concitar valorações jurídicas independentes da vontade das partes:

\begin{abstract}
Cremos, todavia que, em rigor, estas últimas posições só logram justificar-se como contratualistas se, abandonando a concepção corrente de contrato como 'ato de conformação criadora segundo a vontade (dos contraentes) de harmonia com o princípio da autonomia privada', dão dele uma noção objetivada, identificando-o com um comportamento jurídico relevante, capaz de concitar valorações jurídicas independentes da vontade das partes e, assim, de funcionar como causa - entendida de modo objetivo dos deveres de proteção. Substituindo-se o contrato 'querido' pelo contrato 'justo' ou 'adequado', escancaram-se-lhe as portas à entrada desses deveres, os quais passam a acrescentar-se ao programa obrigacional que é posto diretamente pelas partes, sempre que a execução deste envolver de fato riscos para a integridade de bens e pessoas.

Como consequiência forçosa dessa posição teremos admitido um dualismo no direito dos contratos: ao lado dos efeitos ex voluntae, reconhecer-se-ão conseqüências contratuais que prescindem do consenso como elemento de conexão ao contrato. Mas, se assim é, corre-se o risco de atingir no coração a legitimação voluntarística deste instituto, porque talvez se deva dizer com Mayer-Maly que 'o acordo material (de vontades) apenas pode ser encarado sempre ou então nunca como base e legitimação de vinculações contratuais $^{94}$.
\end{abstract}

Assim, consoante Manuel Carneiro da Frada, é só desnaturando a noção de contrato, fundado na autonomia privada, que se pode admitir o acordo de vontades como causa dos deveres laterais ou acessórios de conduta. Atribuindo-se a esses deveres um fundamento na noção objetivada de contrato, e sendo o seu resultado hibridamente conformado e imputado às partes, já se abandonou o campo da autonomia privada e se ingressou no campo da disciplina heterônoma de uma dada relação ${ }^{95}$.

\footnotetext{
${ }^{94}$ FRADA, Manuel A. Carneiro da. op. cit. p. 62-63.

${ }^{95}$ FRADA, Manuel A. Carneiro da. op. cit. p. 62-63.
} 
Não obstante essas respeitáveis posições doutrinais, às quais comungávamos outrora $^{96}$, não podemos deixar de nos referir a um fator fundamental que deve ser levado em consideração na matéria: a causa final ou sinalagmática do contrato.

Para a determinação da natureza contratual, fundada na boa-fé objetiva, dos deveres laterais de conduta pós-eficazes à extinção das obrigações nucleares do contrato há que se considerar essa causa final ou sinalagmática do contrato. A causa final é para cada contratante a sua atividade, o comportamento que leva ao adimplemento, que é também desejado. Esse comportamento não pode ser visto apenas como uma auto-venda, mas deve ser uma atuação leal, sem que isso signifique que seja um ato de caridade. No microcosmo da relação jurídica obrigacional contratual, as partes devem agir tomando em consideração o interesse comum, que é o cumprimento dos deveres contratuais na sua integralidade ${ }^{97}$. Desta forma, a causa do contrato é mais concretamente entendida, em um ordenamento informado pela boa-fé, como a inteira higidez da totalidade da relação jurídica, concebida como um processo, na fase das tratativas, da execução e mesmo após a extinção das obrigações nucleares, de modo que não se frustre de nenhum modo significativo as vantagens e prerrogativas obtidas que decorrem da natureza típica da avença, até o prazo prescricional da obrigação respectiva. Foi o que preconizou a Comissão Conjunta Permanente para a Revisão e Reforma do Código Civil de Porto Rico, ao prever, no art. 45 do Anteprojeto de Código Civil, uma cláusula geral de responsabilidade por comportamento pós-contratual, dispondo que, quem frustre a vantagem outorgada no contrato, ou viole o dever de confidencialidade, deve ressarcir o dano causado. Essa responsabilidade inicia-se com a satisfação da prestação principal do contrato e subsiste até que vença o prazo de prescrição que toda obrigação exige $^{120}$.

Paula Forgioni ao tratar da causa do negócio no direito comercial acentua que esta assume importância, porque permite a objetivação do comportamento do comerciante no mercado e, com isso, a possibilidade de seu cálculo pelo outro. A atenção à causa do negócio transforma-se em fator intrinsecamente ligado à proteção da legítima expectativa da outra

\footnotetext{
${ }^{96}$ Ver em MOTA, Mauricio. Questões de direito civil contemporâneo. Rio de Janeiro ; Elsevier, 2008, pp. 257 304.

${ }^{97}$ PENTEADO,Luciano de Camargo. Doação com encargo e causa contratual. São Paulo : Milennium, 2004, p. 78.
} 
parte, da chamada boa-fé objetiva e à gestão de uma economia capitalista, ou às regras de bom funcionamento do mercado; Evita-se, a todo custo, a tomada de decisões judiciais que fujam da racionalidade própria do agente empresarial, rebatida na boa-fé e na proteção da legítima expectativa. A previsão do standard do homem "ativo e probo" nada mais é senão a assunção de uma racionalidade própria aos empresários (socialmente típica) depurada pelo direito como padrão interpretativo; possibilita-se a proteção da eficiência das decisões empresariais também é outra fonte em que há muito se fartam nossos intérpretes autênticos e nosso ordenamento jurídico. Conclui a citada autora que, quando o elemento jurídico, passa pela interpretação das avenças, dos direitos e das obrigações comerciais, reanimando conceitos clássicos como boa-fé, proteção da legítima expectativa da outra parte ele redimensiona e dá novo fôlego à teoria da causa do negócio jurídico ${ }^{121}$.

A higidez de toda relação contratual, que ela alcance os fins típicos que lhe são próprios (sua função econômico-social) é a causa sinalagmática. Para tanto, nas relações que as pessoas travam entre si, forma-se um tipo especial de contato, que delineia a esfera contratual, com os deveres que até então demarcavam a conduta intersubjetiva adquirindo uma qualificação adicional, e o seu desrespeito passando a ser tratado como inadimplemento, podendo ou não afetar ineludivelmente a relação contratual ${ }^{98}$.

A entrada no contato contratual traduz uma vinculação acrescida, manifestada na oneração com deveres de agir, sempre que seja possível e razoável proceder de modo a evitar que o parceiro contratual sofra um prejuízo durante a vida da relação, mesmo quando o risco não resulte de nenhuma atuação prévia do sujeito. Os deveres laterais de conduta são agora o precipitado jurídico das exigências de lealdade e lisura postas à conduta das partes ou, se se quiser, correspondem a uma moral de interação contratual ${ }^{99}$.

No que se refere aos deveres laterais de conduta, a ilicitude não é indicada automaticamente pela produção (adequada) de uma lesão no direito subjetivo de outrem. Necessita antes de ser positivamente determinada pela ponderação de diversos fatores, com relevo naturalmente para a periculosidade de um determinado comportamento no confronto

\footnotetext{
${ }^{98}$ SILVA FILHO, José Carlos Moreira da. Hermenêutica filosófica e direito: o exemplo privilegiado da boafé objetiva no direito contratual. 2. ed. Rio de Janeiro: Lúmen Juris, 2006, p. 210.

${ }^{99}$ FRADA, Manuel A. Carneiro da. op. cit. p. 266.
} 
com a necessidade de proteção do potencial lesado, para as próprias concepções dominantes no tráfego jurídico, eventualmente até para a utilidade social da atividade portadora de riscos etc. Isto implica na elaboração judicial de normas de conduta cujo desrespeito seja havido em princípio como ilícito ${ }^{100}$.

Avulta que na violação da integridade decorrente dos deveres laterais de conduta, deve-se sediar a conduta lesiva não já em juízos abstratos ou generalizantes ligados à tutela erga omnes desses bens, como é típico do direito delitual, e sim na concreta ponderação dos riscos específicos a que as partes estão expostas no quadro de uma relação particular de tipo contratual. O ângulo de visão como que se modifica, ao se deslocar a fundamentação do dever jurídico de indenizar, do resultado danoso de um bem absolutamente proibido tout court, para se fixar antes na violação dos padrões de comportamento $^{101}$.

Esses deveres laterais de conduta no período pós-contratual mantêm suas qualidades de contatos negociais especialmente qualificados, mas agora não pelas operações econômicas que caracterizavam o contrato (obrigações principais), mas sim como relações fáticas, comportamentos socialmente típicos, para assegurar o escopo e a higidez da inteira relação obrigacional até que seus efeitos se esgotem totalmente pelo decurso do prazo prescricional. Assim sendo, não se dirigem os deveres acessórios póscontratuais ao cumprimento da obrigação principal (já executada), mas à realização do fim contratual e da proteção da outra parte, dos seus interesses e da sua esfera jurídica pessoal e patrimonial, dada a relação de confiança fundamentada pelo próprio contrato executado.

Não se pode, igualmente, olvidar que, no direito brasileiro, a jurisprudência tem se manifestado favoravelmente à compreensão da contratualidade dos deveres laterais ${ }^{102}$ , máxime os de proteção, vislumbrando a violação como hipótese de inadimplemento, como

\footnotetext{
${ }^{100}$ FRADA, Manuel A. Carneiro da. op. cit. p. 164-165

${ }^{101}$ FRADA, Manuel A. Carneiro da. op. cit. p. 169.

${ }^{102}$ BRASIL. Superior Tribunal de Justiça. Recurso Especial n 595.631-SC. Relatora: Ministra Nancy Andrighi. Julgado em 08 de junhp de 2004. Recurso especial. "Civil. Indenização. Aplicação do princípio da boa-fé contratual. Deveres anexos ao contrato. O princípio da boa-fé se aplica às relações contratuais regidas pelo CDC, impondo, por conseguinte, a obediência aos deveres anexos ao contrato, que são decorrência lógica deste princípio. O dever anexo de cooperação pressupõe ações recíprocas de lealdade dentro da relação contratual. A violação a qualquer dos deveres anexos implica inadimplemento contratual de quem lhe tenha dado causa. A alteração dos valores arbitrados a título de reparação de danos extrapatrimoniais somente é possível, em sede de
} 
se pode constatar, dos Enunciados n ${ }^{\circ}$ s 24 e 26 da I Jornada de Direito Civil do Superior Tribunal de Justiça:

\footnotetext{
"Enunciado n ${ }^{\circ}$ 24: Em virtude do princípio da boa-fé, positivado no art.422 do novo Código Civil, a violação dos deveres anexos constitui espécie de inadimplemento, independentemente de culpa".

"Enunciado n 26: A cláusula geral contida no art. 422 do Novo Código Civil impõe ao juiz interpretar e, quando necessário, suprir e corrigir o contrato segundo a boa-fé objetiva, entendido como a exigência de comportamento leal entre os contratantes".
}

Jorge Cesa Ferreira da Silva fundamenta essa idéia no próprio escopo da boa-fé objetiva, no qual a contratualidade dos deveres laterais enseja a melhor solução para os interesses das partes.

Assim, diz o autor, imagine a hipótese em que a execução do contrato, por conduta negligente de uma das partes, não só imponha um dano à outra, mas também demonstra potencialidade de produzir novos danos.

Nesse caso, há, evidentemente, meios para obter-se proteção aos bens jurídicos do lesado, por via da responsabilidade aquiliana. Contudo, se aceitarmos a conduta do lesante e os danos dela originados, como extracontratuais, o lesado poderá optar por duas das seguintes opções: manter o contrato e ajuizar, a cada dano provocado, uma ação reparatória, ou resolver o contrato. Caso opte pela resolução do contrato, o lesado deverá arcar com todas as conseqüências decorrentes dessa opção, desde pagar indenização ou valor fixado em cláusula penal, até a perda de direitos face à ausência de fundamento contratual para a extinção unilateral do vínculo.

Se admitirmos a hipótese, entretanto, como violação de dever contratual lateral de proteção, o dano provocado e a conduta negligente do lesante se caracterizarão como inadimplemento, possibilitando a resolução do contrato cumulada com indenização, a recusa legal da prestação e a possibilidade de mover a exceção do contrato não cumprido.

Do contrário, as vias estarão fechadas, impondo, então, ao contratante vítima

Recurso Especial, nos casos de em que o quantum determinado revela-se irrisório ou exagerado. Recursos não providos". 
de danos ao seu patrimônio pela atuação culposa da outra parte na execução do contrato, o cumprimento da obrigação e o ajuizamento de demanda para reparação de danos ${ }^{103}$.

Também Rogério Ferraz Donnini aduz que é mais simples, ao menos teoricamente, a demonstração da culpa de uma das partes, resultante de um contrato, mesmo após o seu término, pois esta é reconhecida sem esforço, sendo os termos contratuais facilmente identificáveis, assim como menos árduo é o exame da eventual infringência dos deveres acessórios ${ }^{104}$.

Na França, Geneviève Viney aponta a tendência a aplicar o regime contratual à responsabilidade pós-contratual ${ }^{105}$. É a hipótese que ela aponta de decisão da Cour de Cassation sobre as relações jurídicas ocorridas após a locação. No caso, uma das partes, o locador, informou ao locatário sua vontade de não mais prosseguir naquela relação contratual, sendo fixado prazo obrigatório para a saída desse locatário do imóvel. Não obstante isso, o locatário permaneceu no imóvel e sobreveio um incêndio que destruiu o mesmo. A Cour de Cassation decidiu então que o dever pós-eficaz de entregar o imóvel rege-se pela aplicação da responsabilidade contratual (responsabilidade contratual do locatário por danos causados por incêndio no imóvel, conforme previsto no art. 1733 do Código Civil francês) em referência ao contrato extinto ${ }^{106}$. Em sentido oposto, em posição mais tradicional, os irmãos Mazeaud, estabelecendo que no dia em que o contrato desaparece, ele deixa de produzir efeitos, da mesma forma que antes do nascimento, não tendo mais força, a partir do seu desaparecimento, para mudar a natureza da responsabilidade. Esta não pode ser, portanto, senão delitual ${ }^{107}$.

Na Argentina, Ricardo Luis Lorenzetti, preconiza o caráter contratual ao dispor

\footnotetext{
${ }^{103}$ Jorge Cesa Ferreira da Silva, A boa-fé e a violação positiva do contrato. op. cit., p. 87.

${ }^{104}$ DONNINI, Rogério Ferraz. Responsabilidade pós-contratual no novo Código Civil e no Código de Defesa do Consumidor. São Paulo: Saraiva, 2004, p. 149. 105

VINEY, Geneviève. Introduction à la responsabilité. 3 . éd. Paris : Librairie Générale de Droit et de Jurisprudence, 2008, p. 546.

${ }^{106}$ Cour de Cassation. Chambre commerciale. Lecture du 27 mars 1990. n88-20.472. Président :M. Hatoux conseiller doyen faisant fonction. Rapporteur: M. Patin. Bail expiré. La responsabilité qui incombe aux locataires en cas d'incendie, en application de l'art. 1733, ne cesse pas par le fait qu'ils se sont perpétués dans les lieux loués au-delà de l'expiration du bail et contre la volonté du propriétaire. Com. 22 oct. 1962: Bull. civ. III, no 40927 mars 1990.

${ }^{107}$ MAZEAUD, Henri \& MAZEAUD, Leon. Traité théorique et pratique de la responsabilité civile délictuelle et contractuelle. 4. éd. T. 1. Paris: Librairie du Recueil Sirey, 1947, p. 133.
} 
que a responsabilidade pós-contratual se caracteriza por ser uma conduta violadora de um dever colateral baseado no acordado pelas partes ou na boa-fé, que lesiona a posição jurídica de pleno gozo dos bens após o cumprimento do contrato, preconiza o caráter contratual dessa modalidade de responsabilidade. Explica o autor que, cumpridas as obrigações nucleares do contrato existe uma situação estável que é perturbada pelo fato ilícito pós-contratual, ou seja, pela responsabilidade pela violação dos deveres de boa-fé, que afetam o pleno gozo do cumprimento do contrato. Para Lorenzetti, esses deveres subsistem até o prazo máximo da prescrição ou quando deixaram de ser relevantes por carecer de nexo causal com a situação contratual $^{108}$.

Na busca dos vetores materiais que concretizam a boa-fé nas ocorrências de pós-eficácia, deparam-se, no essencial, a confiança e a materialidade das situações em jogo. A confiança requer a proteção, no período subseqüente ao da extinção do contrato, das expectativas provocadas na sua celebração e no seu cumprimento, pelo comportamento dos intervenientes. A materialidade das situações exige que a celebração e o acatamento dos negócios não se tornem meras operações formais, a se desenvolver numa perspectiva de correspondência literal com o acordado, mas que, na primeira oportunidade, se esvaziam de conteúdo. O escopo contratual não pode ser frustrado a pretexto de que a obrigação se extinguiu $^{109}$.

Acórdão do Tribunal Superior do Trabalho ${ }^{110}$ bem gizou o caráter contratual de tais deveres laterais de conduta. Versava o pleito sobre participação nos lucros que se pretendia que fosse estendida aos aposentados, participação este prevista, não em lei, mas em acordo coletivo da categoria, ocorrido após a aposentadoria dos originalmente demandantes, mas antes de transcorrido o prazo prescricional qüinqüenal referido no art. $7^{\circ}$, XXIX, da Carta Política. Assim, a pretensão surgiu após finda a relação de emprego, tratando-se de hipótese de responsabilidade pós-contratual, quando o direito é violado depois de extinto o contrato de emprego. O Tribunal conheceu do Recurso de Revista, firmando o entendimento,

\footnotetext{
${ }^{108}$ LORENZETTI, Ricardo Luis. Tratado de los contratos. Parte general. Santa Fé : Rubinzal-Culzoni Editores, 2004, p. 633/635.

${ }^{109}$ CORDEIRO, Antonio Menezes. Da boa-fé no direito civil. v. 1. op. cit., p. 630.

${ }^{110}$ BRASIL. Tribunal Superior do Trabalho. 4a Turma. Acórdão. Proc. n ${ }^{\text {o }}$ TST-RR-18594/2004-002-09-00.0. Relator: Ministro Barros Levenhagen. Disponível em: 〈www.tst.gov.br〉 Acesso em: 26 de outubro de 2008.
} 
em tese, de que pode haver violação da higidez da relação obrigacional finda por comportamento pós-contratual. Na hipótese, entretanto, negou o pretenso direito sob o argumento de que se impõe prestigiar e valorizar a negociação coletiva assentada na boa-fé, como forma de incentivo à concessão de novas condições de trabalho e de salário, cujos termos devem ser observados de maneira estrita e não extensiva. Assim, em virtude dessa gênese contratual e da evidência de o ajuste ali firmado ter preconizado que a participação nos lucros seria paga apenas aos empregados da ativa, considerou que a decisão de origem, ao estendê-la aos aposentados, violou literal e frontalmente o artigo $7^{\circ}$, inciso XXVI, da Constituição.

Do mesmo modo, em acórdão lavrado pelo Desembargador Ruy Rosado de Aguiar Júnior, ficou assentado que, se um contratante, após o cumprimento das obrigações principal e secundária relativa à compra e venda de um imóvel (pagamento do preço/ escritura e transferência da posse) descumpre o dever lateral de não garantir à nova proprietária a fruição do resultado do contrato, desalojando-a do imóvel, o descumprimento do dever, de tão grave, enseja a resolução do contrato. Logo, é o regime jurídico contratual que rege os deveres laterais de conduta no período pós-contratual ${ }^{111}$. Aduz Ruy Rosado de Aguiar Júnior em seu livro, que "é possível exigir-se das partes, para depois da prestação principal, uma certa conduta, desde que indispensável à fruição da posição jurídica adquirida pelo contrato. É o dever do modelista de não entregar ao concorrente os mesmos modelos com os quais cumprira a sua prestação." 112

O contrato celebrado e executado é o suporte para a apreensão dessas relações pós-contratuais. O poder contratual de apreensão das relações pós-contratuais depende de sua função econômico-social, de sua causa sinalagmática. Assim, é da natureza de cada contrato, em seus efeitos típicos, que se apreendam quais são os deveres laterais de conduta na fase pós-contratual. Por exemplo, a lei brasileira é silente quanto ao dever de sigilo a ser

\footnotetext{
${ }^{111}$ Ementa. Compra e venda. Culpa post pactum finitum. O vendedor que imediatamente após a venda torna inviável à compradora dispor do bem, ameaçando-a de morte e a escorraçando do lugar, para aproveitar-se disso e vender a casa para outrem, descumpre uma obrigação secundária do contrato e dá motivo à resolução. Princípio da boa-fé. Preliminar de nulidade rejeitada. Apelo provido em parte, apenas para suspender a exigibilidade dos ônus de sucumbência. (Apelação Cível No 588042580, Quinta Câmara Cível, Tribunal de Justiça do Rio Grande do Sul, Relator: Ruy Rosado de Aguiar Júnior, Julgado em 16/08/1988)

${ }^{112}$ AGUIAR JÚNIOR, Ruy Rosado de. Extinção dos contratos por incumprimento do devedor (resolução). 2. ed. Rio de Janeiro : AIDE, 2003, p. 253.
}

Revista Quaestio luris, vol.04, no01. ISSN 1516-0351 p.351-423 415 
observado pelas partes em procedimentos arbitrais. Não obstante, é possível inferir da causa sinalagmática do procedimento arbitral essa obrigação de confidencialidade, mesmo na ausência de regulamento expresso da Câmara Arbitral ou de previsão na cláusula compromissória para tanto. A confidencialidade é uma expectativa das partes ao elegerem a via arbitral para a solução de suas controvérsias. Ao buscarem um caminho que possa assegurar a confidencialidade, as partes estimam que, para a condução de seus negócios e operações e continuidade da sua relação negocial, o conhecimento por parte do público da mera existência da controvérsia ou de dados e informações que sejam trazidos à discussão será deletério, podendo, inclusive, causar danos a seus interesses e patrimônio. Assim, por natureza, a confidencialidade é inerente ao procedimento arbitral e essa obrigação, fundada na boa-fé objetiva, subsiste no período pós-contratual até o advento do prazo prescricional, ou, quando deixar de ser relevante por carecer já de nexo causal com a situação contratual, como já dito anteriormente.

A conduta leal é amparada, portanto, pelo princípio constitucional da solidariedade social ${ }^{137}$, também manifestada pelo dever de cooperação mútua, cabendo a cada contraparte buscar, além da satisfação de suas necessidades, a realização dos interesses do outro, quer nas tratativas, quer no decorrer da execução do negócio jurídico, assim como no momento posterior à sua conclusão.

Entretanto, deve-se salientar que as estipulações contratuais dos contratos executados são inaplicáveis aos deveres laterais de conduta pós-contratuais. Tendo o contrato já sido executado em sua obrigação principal, não há que se cogitar de uma ultratividade do seu conteúdo. Só o fato mesmo da existência anterior de um contrato pode ser levado em conta.

Assim, se um contrato já está extinto, por vontade das partes ou por resilição unilateral de uma delas (quando permitido) e, se, não obstante isso, serviços ainda foram prestados, sem ânimo comum de repristinação do contrato extinto, devem estes serviços ser remunerados (para que não haja o enriquecimento sem causa), mas não nos termos das cláusulas contratuais do contrato executado, e sim de acordo com as taxas usuais de mercado. Foi o que decidiu, por exemplo, o Tribunal de Justiça do Rio de Janeiro em litígio sobre acordo operacional, de gerenciamento de parte da carteira de ações, treinamento 
especializado de empregados credenciados e franqueamento de acesso on line a informações de banco de dados. Na hipótese decidiu o Tribunal que, extinto o contrato pela resilição após aviso-prévio, os serviços posteriormente executados remuneram-se pelas taxas usuais do mercado e não pelo conteúdo do contrato ${ }^{138}$. Assim, só o fato do contrato foi levado em conta, porque não mais poderiam ser aplicáveis os dispositivos e condições da obrigação principal, uma vez que a mesma já havia sido executada em sua totalidade.

Em resumo, podemos concluir que os deveres laterais de conduta, pós-eficazes e inerentes ao negócio se configuram como decorrentes de uma vinculação contratual e se dirigem à realização do fim do contrato, à sua causa sinalagmática, entendida essa como a higidez de toda a relação jurídica realizada, de modo que não se frustre a vantagem outorgada no contrato. Cabe ressaltar que, esses deveres subsistem até a perda de sua relevância, seja pelo carecimento de nexo causal com a situação contratual, seja pelo vencimento do prazo de prescrição, característico de toda obrigação.

\section{Conclusão}

Resulta do longo percurso já realizado nesse estudo a evidência de que a responsabilidade pós-contratual já é uma realidade em nosso direito, a partir do advento do Código Civil de 2002. Em nosso primeiro estudo sobre essa matéria ${ }^{113}$, vislumbrávamos o ainda tímido o titubeio da doutrina e da jurisprudência no reconhecimento no direito brasileiro de já não tão nova forma de responsabilização.

Agora, em um direito civil informado pela boa-fé objetiva, pelo equilíbrio contratual e pela função social dos contratos, a responsabilidade civil pós-contratual assume o seu papel na formatação do programa contratual, particularizando-se em inúmeras relações pós-contratuais específicas tais como: na cessão de créditos, na qual, realizado o negócio, o cedente continua obrigado a não tolher a posição do cessionário; na expiração um contrato de edição, na qual, no período pós-contratual, o titular do direito de publicação fica obrigado a

\footnotetext{
${ }^{113}$ MOTA, Mauricio. Questões de direito civil contemporâneo. Rio de Janeiro ; Elsevier, 2008, pp. 257-304.
} 
não fazer novas edições antes de esgotadas as anteriores; no contrato de prestação de serviços, no qual o credor que denuncia o contrato por suspeita fundamentada de comportamento criminoso da outra parte, encerrando a relação, pode ser obrigado a darlhe outra vez ocupação, se desfeita a suspeita ou mesmo provada a ausência de culpa; o dever de confidencialidade pós-contratual do médico acerca do tratamento ministrado em determinadas situações, mesmo após o falecimento do paciente; o dever pós-eficaz decorrente do contrato de venda de máquinas específicas e dispendiosas, onde, mesmo sem cláusula expressa, o vendedor tem a obrigação de fornecer ao comprador as peças sobressalentes; no contrato de venda, o dever pós-contratual do vendedor de informar ao comprador os riscos da coisa, se, depois de cumprido o negócio, vier a ter ciência de alguma característica perigosa da coisa vendida; o dever pós-contratual do vendedor de um imóvel, que tem a obrigação de não prejudicar o comprador mediante alteração dos imóveis vizinhos; o técnico industrial que deve manter sigilo sobre os métodos de fabricação usados na empresa em que trabalhou; a obrigação de segredo pós-contratual à qual está jungido o banqueiro que não cessa com a resilição do contrato de guarda; o dever do vendedor, no trepasse do estabelecimento, de não se restabelecer por um prazo determinado e numa área geográfica delimitada, no mesmo ramo de atividade, de modo a não retirar toda ou parte da clientela, privando o comprador do resultado da coisa vendida; o dever do ex-locatário de não turbar a fruição do imóvel pelo proprietário após a extinção do contrato locatício; o dever pós-contratual do vendedor de um imóvel de não impossibilitar ao novo proprietário a fruição do resultado do contrato de compra e venda; a obrigação pós-contratual de confidencialidade das partes, no procedimento arbitral, mesmo na ausência de regulamento expresso da Câmara Arbitral ou cláusula compromissória para tanto etc.

Enfim, inúmeras são as possibilidades de aplicação da pós-eficácia das obrigações e, portanto, avulta a determinação da natureza do instituto.

A pós-eficácia das obrigações, como demonstramos, insere-se no âmbito da função integrativa da boa-fé objetiva como um dever lateral de lealdade. Os deveres laterais de conduta inerentes à boa-fé são deveres funcionalizados ao fim do contrato e, como tal, surgem e se superam no desenvolvimento da situação contratual como uma totalidade, autonomizando-se em relação ao dever de prestação principal, para assegurarem o correto 
implemento do escopo do contrato. Assim, subsistem deveres pós-eficazes ao término do adimplemento do contrato, no interesse da correta consecução deste.

A fundamentação dogmática da pós-eficácia das obrigações está nos princípios sociais do Código Civil: a boa-fé objetiva, o equilíbrio contratual e a função social dos contratos. Assim, devem as partes lealdade à convenção livremente celebrada. A lealdade em causa traduzir-se-ia, nomeadamente, na necessidade jurídica de, para além da realização formal da prestação, providenciar a efetiva obtenção e manutenção do escopo contratual. Essa manutenção do escopo contratual perdura, naturalmente, para além da extinção da obrigação nuclear do contrato, configurando-se, pois, a pós-eficácia.

A pós-eficácia das obrigações constitui um dever lateral ou acessório de conduta unitário de lealdade, de garantia da fruição do contrato realizado. Abrangem esse dever unitário em si os deveres para com a proteção e o esclarecimento da contraparte que, no término do contrato, sem a alteridade da avença, convertem-se em um só dever de assegurar a fruição do resultado do contrato.

A determinação se o implemento de uma determinada conduta constitui ou não um dever lateral da obrigação extinta é dada pela noção de base do negócio jurídico. Existirá tal dever sempre que a atitude de uma das partes da relação contrariar, em infringência à boafé objetiva, a base objetiva do negócio, não permitindo a fruição do resultado do negócio realizado.

Por fim, deve-se salientar, como afirmado, que os deveres laterais de conduta, pós-eficazes e inerentes ao negócio, configuram-se como decorrentes de uma vinculação contratual e se dirigem à realização do fim do contrato, à sua causa sinalagmática, entendida essa como a higidez de toda a relação jurídica realizada, de modo que não se frustre a vantagem outorgada no contrato. Cabe ressaltar que, esses deveres subsistem até a perda de sua relevância, seja pelo carecimento de nexo causal com a situação contratual, seja pelo vencimento do prazo de prescrição, característico de toda obrigação.

Portanto, temos esboçado aqui um instrumental bastante útil para a compreensão da natureza e peculiaridades desse tema tão instigante que é a pós-eficácia das obrigações, possibilitando uma mais efetiva aplicação desta pelos Tribunais nos litígios decorrentes dos contratos. 


\section{Referências}

ABREU, Luís Vasconcelos. O segredo médico no direito português vigente. In: Estudos de Direito da Bioética, Lisboa: Almedina, 2005.

AGUIAR JÚNIOR, Ruy Rosado de. Extinção dos contratos por incumprimento do devedor (resolução). 2. ed. Rio de Janeiro : AIDE, 2003.

ALMEIDA, Francisco de Paula Lacerda de. Obrigações. Rio de Janeiro : Livraria Cruz Coutinho, 1897.

ARISTÓTELES. Ética a Nicômaco. 4. ed. Brasília : UNB, 2001.

AUBRY e RAU. Cours de droit civil français. Tome V. Paris : Librairie Générale de Jurisprudence, 1902.

AZEVEDO, Antonio Junqueira de. Responsabilidade pré-contratual no Código de defesa do consumidor: estudo comparado com a responsabilidade pré-contratual no direito comum. Revista de Direito do Consumidor. n. 18, p. 23-31, abr.-jun., 1996.

AZEVEDO, Antonio Junqueira de. Novos estudos e pareceres de direito privado. São Paulo: Saraiva, 2009.

BACACHE-GIBEILI, Mireille. La relativité des conventions et les groups de contrats. Paris : LGDJ, 1996.

BARBOSA, Rui. As cessões de clientela e a interdição de concorrência nas alienações de estabelecimentos comerciais e industriais. Obras Completas de Rui Barbosa. Vol. XL. Tomo I. Rio de Janeiro : Ministério da Educação e Saúde, 1948.

BECKER, Anelise. Teoria geral da lesão nos contratos. São Paulo : Saraiva, 2000.

CABANILLAS, Renato Rabbi-Baldi. La filosofía jurídica de Michel Villey. Pamplona : Universidad de Navarra, 1990.

CALASTRENG, Simone. La relativité des conventions : étude de l'article 1165 du Code civil. Paris : Recueil Sirey, 1939.

CARDOSO, Patrícia. Oponibilidade dos efeitos dos contratos: determinante da responsabilidade civil do terceiro que coopera com o devedor na violação do pacto contratual. Revista Trimestral de Direito Civil, v. 20, out.-dez. 2004.

COMPARATO, Fábio Konder. A Cessão de Controle Acionário é negócio mercantil? Revista Forense. n. 273, ano 77, jan.-mar., 1981.

CORDEIRO, Antonio Manuel da Rocha e Menezes. Da boa-fé no direito civil. v. 1. Coimbra : Almedina, 1984.

CORDEIRO, Antonio Manuel da Rocha e Menezes. Da pós-eficácia das obrigações. Estudos de direito civil. v. I. Coimbra : Almedina, 1991.

DONNINI, Rogério Ferraz. Responsabilidade pós-contratual no novo Código Civil e no Código de Defesa do Consumidor. São Paulo: Saraiva, 2004.

DWORKIN, Ronald. Levando os direitos a sério. São Paulo: Martins Fontes, 2002.

FONTAINE, Marcel. Les obligations « survivant au contrat». In : COMMISSION UNIVERSITÉ-PALAIS. La fin du contrat. v. 51. Paris : CUP, 2001.

FORGIONI, Paula Andrade. Contrato de distribuição. 2. ed. São Paulo : Revista dos Tribunais, 2008.

FRADA, Manuel A. Carneiro da. Contrato e deveres de protecção. Coimbra : Coimbra, 1994.

Revista Quaestio luris, vol.04, no01. ISSN 1516-0351 p.351-423 420 
GARCIA, Enéas Costa. Responsabilidade pré e pós-contratual à luz da boa-fé. São Paulo: Juarez de Oliveira, 2003.

GATSI, Jean. Le contrat-cadre. Paris : LGDJ, 1996.

GOMES, Orlando. Contratos. Rio de Janeiro : Forense, 1966.

GOUNOT, Emmanuel. Le principe de l'autonomie de la volonté en droit privé : contribution à l'étude critique de l'individualisme juridique. Paris : Arthur Rousseau, 1912.

GRECHI, Frederico Price. A cláusula de não concorrência na cessão do estabelecimento empresarial na perspectiva civil-constitucional. In: GAMA, Guilherme Calmon Nogueira da \& ALVES, Alexandre Ferreira de Assumpção (orgs.). Temas de Direito civil-empresarial. Rio de Janeiro : Renovar, 2008.

IHERING, Rudolf Von. Do lucro nos contractos e da supposta necessidade do valor patrimonial das prestações obrigatórias. Questões de direito civil. Rio de Janeiro : Laemmert Editores, 1899.

JAMIN, Christophe. La notion d’action directe. Paris : LGDJ, 1991.

JOSSERAND, Louis. De l'esprit des droits et de leur relativité - Théorie dite de l'Abus des droits. Paris : Dalloz, 1927.

JUSTINIANO. Cuerpo del derecho civil romano. Tomo III. Digesto. $6^{\mathrm{a}}$ y $7^{\mathrm{a}}$ partes. Tradução de Idelfonso García del Corral. Valladolid : Lexnova, 1988.

JUSTINIANO. Digesto de Justiniano. Livro I. Tradução de Hélcio Maciel França Madeira. São Paulo : Revista dos Tribunais/UNIFIEO, 2000.

LARENZ, Karl . Derecho de obligaciones. Madri : Revista de Derecho Privado, 1958.

LARENZ, Karl. Base del negocio juridico y cumplimiento de los contratos. Madri : Revista de Derecho Privado, 1956.

LARENZ, Karl. Derecho justo: fundamentos de etica juridica. Madri : Civitas, 1993.

LE STANC, Christian. Existe-t-il une responsabilité postcontractuelle?, Chronique au JCP-CI, 1978, 12735.

LESSA, Pedro. Debate e julgamento no Supremo Tribunal Federal da Apelação Cível no 2183. Sessão de 12 de agosto de 1914. In: BARBOSA, Rui. As cessões de clientela e a interdição de concorrência nas alienações de estabelecimentos comerciais e industriais. Obras Completas de Rui Barbosa. Vol. XL. Tomo I. Rio de Janeiro : Ministério da Educação e Saúde, 1948.

LORENZETTI, Ricardo Luis. Tratado de los contratos. Parte general. Santa Fé : Rubinzal-Culzoni Editores, 2004.

MARTINS-COSTA, Judith. A boa-fé no direito privado: sistema e tópica no processo obrigacional. São Paulo : Revista dos Tribunais, 1999.

MARTINS-COSTA, Judith \& BRANCO, Gerson Luiz Carlos. Diretrizes teóricas do novo Código Civil brasileiro. São Paulo: Saraiva, 2002.

MARTORELL, Juan Terraza. Modificación y resolución de los contratos por excesiva onerosidad en su ejecución. Barcelona : Bosch, 1951.

MAZEAUD, Henri \& MAZEAUD, Leon. Traité théorique et pratique de la responsabilité civile délictuelle et contractuelle. 4. éd. t. 1. Paris: Librairie du Recueil Sirey, 1947.

MELO, Diogo Leonardo Machado de. Notas sobre a responsabilidade pós-contratual. In: NANNI, Giovanni Ettore (Org.). Temas relevantes do direito civil contemporâneo. São Paulo: Atlas, 2008.

MENDONÇA, Joaquim Xavier Carvalho de. Apelação no 2183. Memorial da Apelante ao Supremo Tribunal Federal. Rio de Janeiro : Liga Marítima Brasileira, 1912.

MOTA, Mauricio. Questões de direito civil contemporâneo. Rio de Janeiro ; Elsevier, 2008.

Revista Quaestio luris, vol.04, no01. ISSN 1516-0351 p.351-423 421 
MOTA, Mauricio. A pós-eficácia das obrigações. In: TEPEDINO, Gustavo (org.). Problemas de direito civilconstitucional. Rio de Janeiro : Renovar, 2000.

NORONHA, Fernando. O direito dos contratos e seus princípios fundamentais: autonomia privada, boa-fé e justiça contratual. São Paulo : Saraiva, 1994.

NORONHA, Fernando. Direito das obrigações: fundamentos do direito das obrigações. v. 1. São Paulo : Saraiva, 2003.

PENTEADO, Luciano de Camargo. Doação com encargo e causa contratual. São Paulo : Milennium, 2004.

PÉROT-MOREL, Marie-Angèle. De l'equilibre dês prestations dans la conclusion du contrat. Paris : Dalloz, 1961.

PINTO, Carlos Alberto da Mota. Cessão de contrato. São Paulo : Saraiva, 1985.

POTHIER, R-J. Tratado das obrigações pessoaes e recíprocas. t. 1. Rio de Janeiro : H. Garnier Editor, 1906.

RENNER, Rafael. Novo direito contratual: a tutela do equilíbrio contratual no Código Civil. Rio de Janeiro : Freitas Bastos, 2007.

SÁNCHEZ, Noelía de Miguel. Secreto médico, confidencialidad e información sanitária. Madrid: Marcial Pons, 2002.

SAVIGNY, Friedrich Karl Von. Le droit des obligations. v. 1. Paris, s.e., 1873.

SAVIGNY, Friedrich Karl Von. Sistema del derecho romano actual. t. 2. Madri : F. Góngora Editores, 1879.

SEIBT-FOMBART, Fabiola Oliveira. Les relations post-contractuelles. Memoire pour le Diplome d'Études Approfondis. Faculté de Droit. Université Robert Schuman de Strasbourg. Strasbourg. 2002. Disponível em: <www-cde.u-strasbg.fr/da/da/AnnexesMemoires/Promo2002/seibt.pdf> . Acesso em: 19 de outubro de 2008.

SILVA FILHO, José Carlos Moreira da. Hermenêutica filosófica e direito: o exemplo privilegiado da boa-fé objetiva no direito contratual. 2. ed. Rio de Janeiro: Lumen Juris, 2006.

SILVA, Clóvis Veríssimo do Couto e. O princípio da boa-fé no Direito brasileiro e português. In: FRADERA, Vera Maria Jacob de (Org.). O direito privado brasileiro na visão de Clóvis do Couto e Silva. Porto Alegre : Livraria do Advogado, 1997.

SILVA, Clóvis Veríssimo do Couto e. O direito civil brasileiro em perspectiva histórica e visão de futuro. In: FRADERA, Vera Maria Jacob de (Org.). O direito privado brasileiro na visão de Clóvis do Couto e Silva. Porto Alegre : Livraria do Advogado, 1997.

SILVA, Clóvis Veríssimo do Couto e. Obrigação como processo. Rio de Janeiro : FGV, 2006.

SILVA, Jorge Cesa Ferreira da. A boa-fé e a violação positiva do contrato. Rio de Janeiro : Renovar, 2002.

SILVA, Luís Renato Ferreira da. A função social do contrato no novo Código Civil e sua conexão com a solidariedade social. In: SARLET, Ingo (Org.). O Novo Código Civil e a Constituição. Livraria do Advogado, 2003.

TREVISAN, Marco Antônio. Responsabilidade civil pós-contratual. Revista de Direito Privado. São Paulo, n. 16, out.-dez., 2003.

VILLEY, Michel. Abrégé du droit naturel classique. Archives de Philosophie du Droit. Paris, n. 6, p. 25-72, 1961.

VILLEY, Michel. Seize essais de philosophie du droit dont un sur la crise universitaire. Paris : Dalloz, 1969.

VINEY, Geneviève. Introduction à la responsabilité. 3. éd. Paris : Librairie Générale de Droit et de Jurisprudence, 2008.

VOLTERRA, Eduardo. Instituciones de derecho privado romano. Madri : Civitas, 1991.

Revista Quaestio luris, vol.04, no01. ISSN 1516-0351 p.351-423 422 
ZAVASCKI, Teori Albino. A tutela da posse na Constituição e no projeto do novo Código Civil. In: A reconstrução do Direito Privado. MARTINS-COSTA, Judith (Org.). São Paulo : Revista dos Tribunais, 2002. 